\title{
OVERVIEW AND CHALLENGES OF MARINE BIODIVERSITY RESEARCH IN PERU
}

\author{
UNA REVISION Y DESAFIOS PARA LA INVESTIGACION EN \\ BIODIVERSIDAD MARINA EN PERU
}

\author{
Juan Tarazona ${ }^{1,3}$, Dimitri Gutiérrez ${ }^{2}$, Carlos Paredes ${ }^{3} \&$ Aldo Indacochea ${ }^{1}$ \\ ${ }^{1}$ Dirección General de Programas, Consejo Nacional de Ciencia y Tecnología (CONCYTEC). Apartado 1898, Lima 100, Perú \\ ${ }^{2}$ Laboratorio de Bentos Marino, Dirección de Investigaciones Oceanográficas, Instituto del Mar del Perú (IMARPE). \\ P.O. Box 22, Callao, Perú \\ ${ }^{3}$ Instituto de Ciencias Biológicas Antonio Raimondi, Facultad de Ciencias Biológicas, Universidad Nacional Mayor \\ de San Marcos (UNMSM). P.O. Box 1898, Lima 100, Perú
}

\begin{abstract}
This paper is a panoramic, though incomplete, review of the Peruvian marine biodiversity, including the Peruvian coastal upwelling ecosystem, the marine shallow areas of the Peruvian coast and the mangrove ecosystem of the north of Peru. It includes an analysis of the advances in conservation and management, as well as of research resources. The analysis mainly showed the insufficient human resources and the limited facilities in laboratories and coastal research stations. An analysis was also made from the current unknowns of the research at taxonomy and ecosystem levels, indicating scarce studies for most of the taxonomic groups and biological communities. Finally, the consultations and discussions promoted with the scientific community, allowed the identification of the following issues as the main challenges for future research: formation and training of human resources, development of inventories, studies on endemism and speciation areas, application of new technologies for monitoring physical and biological parameters of the ecosystem, and assessment of the impacts of climate change on marine biodiversity.
\end{abstract}

KEYWORDS: coastal upwelling ecosystem, marine shallow areas, hipoxia, anoxia, Thioploca, mangrove ecosystem of the north, conservation and management.

\section{RESUMEN}

El presente trabajo es una revisión panorámica, aunque incompleta, de la biodiversidad biológica marina del Perú, que incluye el ecosistema de surgencias costeras peruano, las áreas marinas someras de la costa peruana y el ecosistema de manglar del norte del Perú. Incluye un análisis de los avances en conservación y manejo, y de los recursos con que se dispone para la investigación. El análisis mostró principalmente la escasez de recursos humanos y las limitadas facilidades de laboratorios y de estaciones costeras de investigación de que disponen las instituciones. También se hizo un análisis de los vacíos de información a nivel taxonómico y de estudios ecosistémicos, que reflejó una escasez de estudios en la mayoría de grupos taxonómicos y comunidades biológicas. Finalmente, las consultas y discusiones promovidas en el seno de la comunidad científica, permitieron identificar como principales retos para las investigaciones futuras a: la formación y capacitación de recursos humanos, el desarrollo de inventarios taxonómicos, el estudio de endemismos y áreas de especiación, la aplicación de nuevas tecnologías en el monitoreo biótico y abiótico del ecosistema y la evaluación de los impactos del cambio global sobre la biodiversidad marina.

PALABRAS ClaVES: Ecosistema de surgencias costeras, áreas marinas, someras, hipoxia, anoxia, Thioploca, conservación y

manejo.

\section{INTRODUCTION}

The Peruvian coast line is more than $3000 \mathrm{~km}$ long but, in comparison with the terrestrial environments, progress in increasing knowledge and the conservation of the marine ecosystem has been very slow. It is important to point out that marine biological resources have an enormous potential as a source, not only of proteins, but also of a great variety of active principles for use in industrial processes and medi- 
cine. In the last few years, new perspectives have arisen with the advances in biotechnology.

The first investigations on the marine biota of Perú centered on the problems of the exploitation of the guano of the islands. Later, with the development of the anchovy fishery, the focus of research moved to this resource. A diversification of the investigations occurred after the collapse of the anchovy population in the 1970s (Arntz \& Tarazona 1990). However, up to the present time, information about only a very few taxonomic groups has been compiled into lists and catalogues (Chirichigno 1970, 1998; Del Solar et al. 1970; Méndez 1981; Alamo \& Valdivieso, 1987; Paredes et al. 1988).

This paper is a panoramic, though incomplete, review about the main patterns and features of Peruvian marine biodiversity, including the littoral environment, with particular emphasis on the taxonomic, biogeographical and ecosystem aspects. The main factors that might control Peruvian marine biodiversity are also considered. The present analysis constitutes a preliminary interpretation of the current literature and the contributions provided by a number of national scientists.

\section{SUMMARY OF CURRENT KNOWLEDGE}

Present Knowledge of the Peruvian Marine EcoSYSTEM

The main marine ecosystem off Peru is the Peruvian coastal (or Humboldt) upwelling system. This extends from central Chile $\left(\sim 40^{\circ} \mathrm{S}\right)$, to northern Peru $\left(\sim 4-5^{\circ} S\right)$ where there is a dynamic boundary with the Pacific Central American coastal ecosystem (Bakun et al. 1999). The Peruvian marine system is made up of several subsystems: moving from onshore to offshore, these are littoral or intertidal, neritic and oceanic; from the sea surface to the bottom, it is also possible to identify pelagic and benthicdemersal subsystems. In addition, the southernmost limit of the tropical Pacific mangrove ecosystem is located in northern Peru.

\section{The Peruvian Coastal Upwelling Ecosystem}

\section{GenERAL CHARACTERISTICS}

The Peruvian coastal upwelling ecosystem (PCUE) is one of the marine systems of the world with the greatest complexity, variability and productivity. It is subject to significant interannual variability, as a consequence of the ENSO cycle, its warm and cold phases being named El Niño (EN) and La Niña (LN). Among the main oceanographic and ecological features off the Peruvian coast are: i) almost permanent coastal upwelling driven by the southeastern trade winds; ii) a shallow Ekman layer feeding surface filaments that fertilize offshore waters; iii) a predominantly poleward circulation near the coast (Fig. 1) consisting of the Peru Coastal Current, a shallow inshore $(<100 \mathrm{~km})$ equatorward wind-drift current, and the poleward Peruvian Undercurrent (or Gunther current) associated with the core of the oxygen minimum zone (OMZ); iv) a shallow but intense oxygen minimum layer $\left(<0.5 \mathrm{ml} \mathrm{l}^{-1}, \sim 50\right.$ $500 \mathrm{~m}$ ) that intersects the coastal margin (Fig. 2) and affects the biological communities and biogeochemical processes in the water column and in the sediments; v) a poleward Peru-Chile countercurrent, 100-300 km offshore, and an equatorward oceanic current, 600-1000 km offshore; vi) local forcing is modulated by topographic features (e.g. the width of the continental shelf and the coastline angle) but is mainly due to remote forcing in the equatorial Pacific propagated by coastal trapped waves which influence both the physical and biological dynamics of the ecosystem; vii) during nonEN years, average primary production in upwelling waters is around $1 \mathrm{~kg} \mathrm{C} \mathrm{m}^{-2} \mathrm{y}^{-1}$, the highest in the global ocean; viii) the high primary production and the rather simple trophic web of the pelagic subsystem give rise to large populations of small pelagic fish of up to 20-30 million tonnes of total biomass, sustaining one of the main fishery industries of the world; ix) the influence of upwelling extends hundreds of kilometers offshore, favoring the presence of highly migratory fishes and invertebrates.

\section{EXTENSION AND DISTRIBUTION}

The latitudinal range between $4^{\circ}$ and $5^{\circ} \mathrm{S}$, which is the zone of transition between the Peruvian and the Panamanian biogeographical provinces, may be regarded as the northern boundary of the PCUE, as a first approach. The position of this boundary varies, however, on seasonal and interannual scales, since cold upwelled nutrient-rich waters may be advected further north during the austral winter and in LN periods, while they are constrained to south 
Gayana 67(2), 2003

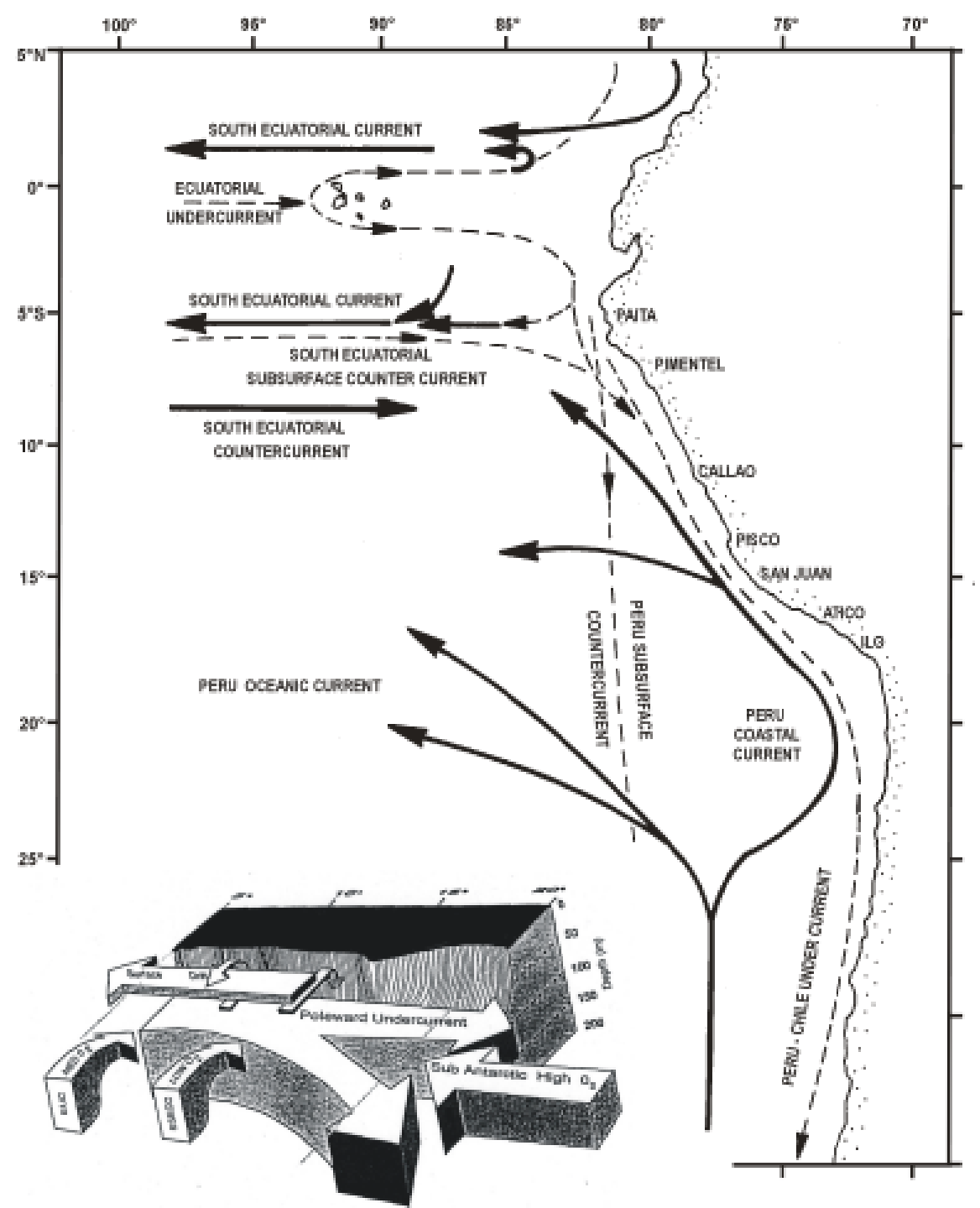

Figure 1. Generalized circulation scheme for the Peruvian coastal upwelling ecosystem and the schematic illustration of upwelling waters. EUC: Equatorial undercurrent, SSECC: Subsurface South equatorial countercurrent (from Codispoti 1989).

Figura 1. Esquema generalizado de la circulación para el ecosistema de surgencia de la costa peruana y la ilustración esquemática de aguas surgentes. EUC: el corriente submarina ecuatorial del sur (de Codispoti 1989). 
of $5^{\circ} \mathrm{S}$ during the austral summer, or even to south of $7^{\circ} \mathrm{S}$ during EN periods (Strub et al. 1998). The offshore limit of the ecosystem is also variable and a matter of discussion. If only the physical domain of upwelling is taken into account, the average extension of the ecosystem would be around $120 \mathrm{~km}$ from the coast, giving an area of $182,000 \mathrm{~km}^{2}$ between $4^{\circ}$ and $18^{\circ} \mathrm{S}$ (Chávez \& Barber 1987). Certainly, the offshore extension of the ecosystem exhibits marked temporal variability: Nixon \& Thomas (2001) used a surface Chl $a$ concentration of $1 \mathrm{mg} \mathrm{m}^{-3}$ as a criterion for the limit of the ecosystem and estimated a total area of $220,000 \mathrm{~km}^{2}(140 \mathrm{~km}$ width on average) for the 1998/1999 LN period, and an area of $120,000 \mathrm{~km}^{2}$ ( $80 \mathrm{~km}$ width on average) for the $1997 /$ $1998 \mathrm{EN}$ period. Seasonal changes in the extension of productive waters are also observed in maps of mean surface Chl $a$ distribution (see Fig. 1 in Calienes et al. 1985). However, it is important to note that the influence of upwelling may extend further offshore. Using a surface $\mathrm{Chl} a$ concentration of $0.5 \mathrm{mg} \mathrm{m}^{-3}$ as the limit would give an offshore extension of $250 \mathrm{~km}$ and a total area of $400,000 \mathrm{~km}^{2}$ for the $1998 / 1999$ period (Nixon \& Thomas 2001). Similar values, $300 \mathrm{~km}$ and $450,000 \mathrm{~km}^{2}$ of width and total area, respectively, are obtained if the concept of a 'biological width' (Cushing 1971), 2.5 times the physical width of upwelling, is adopted.

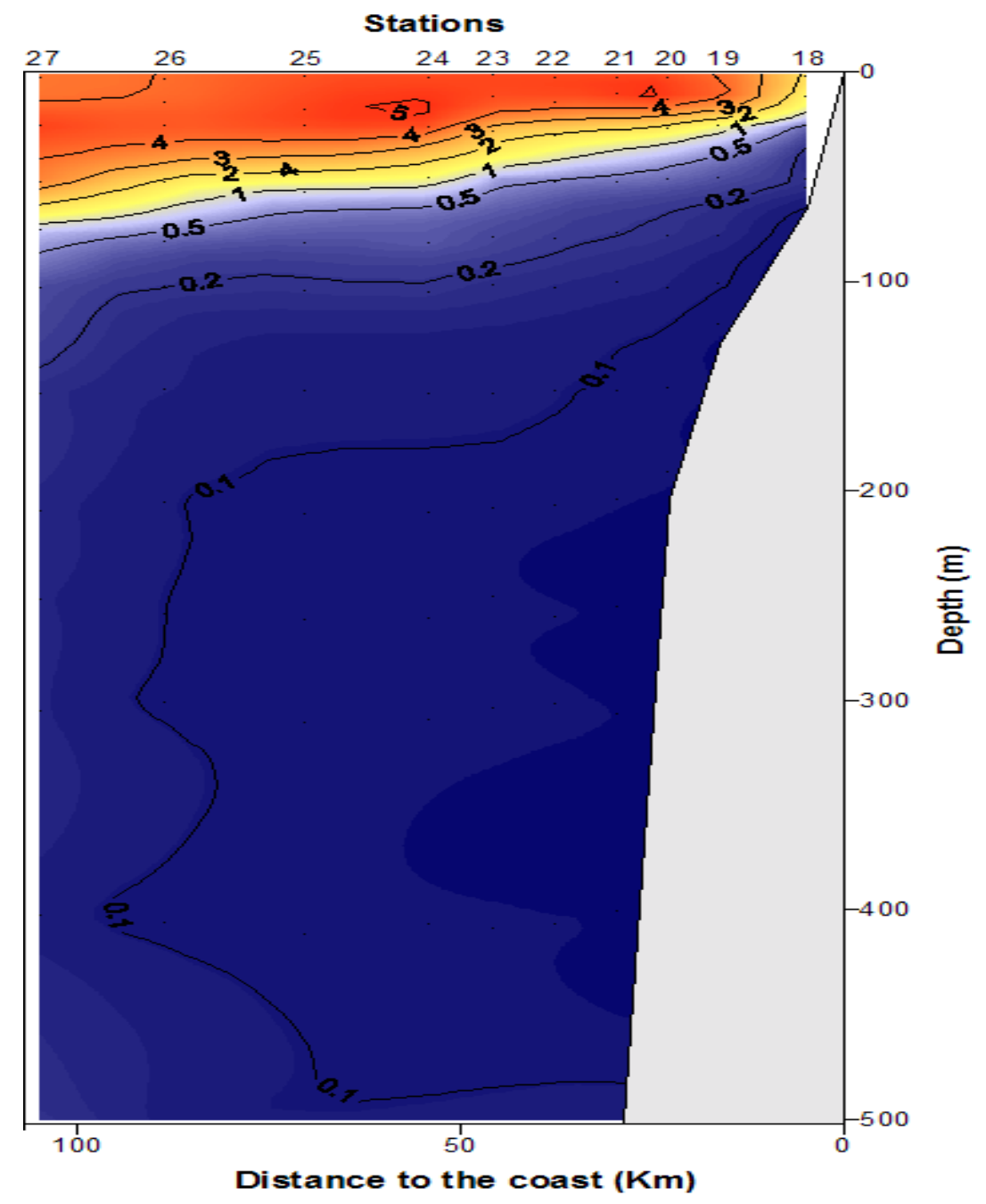

FIGURE 2. Dissolved oxygen concentration of Callao $\left(12^{\circ} \mathrm{S}\right)$ under non El Niño conditions (March 1985; R/V Wecoma).

FiguRa 2. La concentración de oxígeno disuelto frente a Callao $\left(12^{\circ} \mathrm{S}\right)$, bajo condiciones "normales" (no en el tiempo de El Niño) (marzo1985; R/V Wecoma). 
UPWELLING, FERTILITY AND NUTRIENT LIMITATION

Upwelled waters are transported from shallow depths (50-150 m) with low oxygen contents (4 ml $1^{-1}$ ) and high nutrient concentrations (Zuta \& Guillén, 1970; Strub et al. 1998). The upwelling rate off the Peruvian coast reaches $3 \times 1012 \mathrm{~m}^{3} \mathrm{~s}^{-1}$ with ascending velocities of 5-30 x 10 $0^{-5} \mathrm{~cm} \mathrm{~s}^{-1}$ (Strub et al. 1998; Tarazona \& Arntz 2001). The main upwelling centers are located at $4-6^{\circ} \mathrm{S}, 7-9^{\circ} \mathrm{S}, 11-13^{\circ} \mathrm{S}$ and $14-$ $16^{\circ}$ S (Zuta \& Guillén 1970; Rojas De Mendiola 1981). Upwelling is fed by three different sources: the relatively well oxygenated waters of the southern extension of the Cromwell undercurrent, north of $6^{\circ} \mathrm{S}$; the oxygen-deficient waters from the poleward undercurrent are the main source north of $12^{\circ} \mathrm{S}$ and, sometimes (summer/fall), further south; and finally, mixed subantarctic waters and equatorial subsurface waters feed the upwelling south of $14^{\circ} \mathrm{S}$. Upwelling is more intense during the winter, according to the wind pattern off the Peruvian coast (Bakun 1987). The seasonal variation of nutrient concentration follows the temporal regime of upwelling, favoring high rates of new production in the ecosystem ( $f=0.75$; Dugdale 1985). However, nutrient regeneration from the sediments may be significant close to the coast (Harrison \& Platt 1981). Both silicate and nitrate may act as limiting nutrients for phytoplankton growth (Guillén \& Calienes 1981; Calienes et al. 1985), the former when upwelling is weak, and the latter when it strengthens (Dugdale 1983). Nitrate limitation results from high denitrification rates associated with the OMZ (Codispoti \& Packard 1980; Olivieri \& Chávez 1996). Evidence of iron limitation for primary production in the PCUE was recently presented by Hutchins et al. (2002).

\section{PRIMARY AND SECONDARY PRODUCTION}

The average surface Chl $a$ content within $100 \mathrm{~km}$ of the Peruvian coast varies between 1 and $12 \mathrm{mg}$ $\mathrm{m}^{-3}$. The vertically integrated $\mathrm{Chl} a$ content in the euphotic layer ranges from 5 to $200 \mathrm{mg} \mathrm{m}^{-2}$ in the same area. Higher values ( $>5 \mathrm{mg} \mathrm{m}^{-3}$ surface Chl $a$, $>100 \mathrm{mg} \mathrm{m}^{-2}$ integrated $\mathrm{Chl} a$ ) are found within upwelling waters (Calienes et al. 1985). Tongues of surface Chl $a>0.5 \mathrm{mg} \mathrm{m}^{-3}$ are observed with remote sensing at more than $400 \mathrm{~km}$ offshore (F. Chávez pers. comm.). Average primary production rates in the upwelling areas are $>4 \mathrm{~g} \mathrm{C} \mathrm{m}^{-2} \mathrm{~d}^{-1}$ (Calienes et al. 1985). Primary production measurements from 1975 to 1987 within the PCUE by Chávez et al. (1989) gave an overall mean of $3.3 \mathrm{~g}$ $\mathrm{C} \mathrm{m}^{-2} \mathrm{~d}^{-1}\left(1.2 \mathrm{~kg} \mathrm{C} \mathrm{m}^{-2} \mathrm{y}^{-1}\right)$. The high annual productivity of the system results from the ongoing nutrient availability resulting from the persistence of favorable forcing factors during the whole of the year (Pocklington 1981). The seasonal variation of plankton biomass and primary production within $100 \mathrm{~km}$ off the coastline is out of phase with the variation of upwelling intensity (Guillén \& Calienes 1981; Calienes et al. 1985; Chávez 1995; Thomas et al. 2001). Guillén \& Calienes (1981) suggested that higher primary production during summer/fall is explained by the dynamics of the depth of the mixed layer and of solar radiation. However, offshore $(100-250 \mathrm{~km}) \mathrm{Chl} a$ contents are maximal during winter, probably as a result of stronger Ekman transport (Chávez 1995). In contrast with phytoplankton, measurements of bacterial and zooplankton biomass and production are scarce. Bacterioplankton biomass ranges up to $4.0 \mathrm{~g} \mathrm{C} \mathrm{m}^{-2}$ in upwelling waters (Tarazona \& Arntz 2001). Santander et al. (1981) determined the cross-shelf variation of zooplankton biomass off Chimbote $\left(9^{\circ} 15^{\prime} \mathrm{S}\right)$ and found that it ranged between approximately 0.2 and $18.2 \mathrm{~g} \mathrm{~m}^{-2}$ (average $2.54 \mathrm{~g} \mathrm{~m}^{-2}$ ). Mean seasonal zooplankton volumes, from 1964 to 1983, off the Peruvian coast varied between 0.4 and $1.7 \mathrm{ml} \mathrm{m}^{-3}$ (volume of filtered water) with higher values during the spring (Carrasco \& Lozano 1989).

\section{PlankTon COMMUNities}

The phytoplankton community of the coastal upwelling area is composed of early successional stages of mainly small diatoms $(5-30 \mathrm{~mm})$ with high reproduction rates such as Skeletonema costatum Chaetoceros debilis, Ch. curvisetus, Ch. affinis and Detonula pumila (Fig. 3). In later successional stages, it is characterized by species of larger size such Thalassionema nitzschioides, Proboscia alata, Coscinodiscus spp., Lithodesmium undulatum, etc. The change in dominant species is closely related to the transition from turbulent to more stable conditions in upwelled waters. In oceanic waters, the phytoplankton is dominated by dinoflagellates (Ceratium gibberum, C. trichoceros, C. macroceros, C. kofoidii, Protoperidinium oceanicum) and large 
diatoms with low reproduction and assimilation rates (Chaetoceros coarctatus, Ch. peruvianus, Guinardia flaccida, Planktoniella sol, Pseudosolenia calcar avis, Rhizosolenia styliformis, etc.) (Ochoa \& Gómez 1981, 1987, 1997; Ochoa et al. 1999; Sánchez 2000). The zooplankton in upwelled waters is dominated by the copepods Acartia tonsa and Centropages brachiatus and a number of meroplanktonic larvae. Further offshore, near the shelf-break and upper-slope, the dominant copepods are Paracalanus parvus, Calanus spp., Oncaea spp., etc., and other large holoplankters such as siphonophores, cheatognaths and euphausiids (Tarazona \& Arntz 2001). The OMZ constrains the vertical distribution of most of the zooplankton to the upper 30-50 m of the water column (Santander et al. 1981; Sameoto 1981). Among the most conspicuous species limited by the OMZ are P. parvus, $C$. brachiatus, and Oncaea spp. The copepods Eucalanus inermis, Rhincalanus nasutus, and Euaetideus bradyi and the euphausiid Euphausia mucronata are found mainly in oxygen deficient waters. Other large taxa that are found in subsurface oxygen deficient waters are amphipods, ostracods, and polychaetes (Santander et al. 1981). Diel migrations are common among zoop- lankton groups; euphausiids and amphipods are able to migrate deeper than $50 \mathrm{~m}$ and are found near the surface during the night time. Most of the copepods migrate within the upper $50 \mathrm{~m}$ of the water column.

\section{THE BENTHIC COMMUNITY}

The macrobenthic community becomes low in biomass, density, and diversity where oxygen is deficient in bottom waters (> 30-50 m) (Rowe 1971; Rosenberg et al., 1983; Arntz et al. 1991) with polychaetes worms predominating, both in density and biomass $(>80 \%)$. The most abundant species of the continental shelf intersected by the OMZ are the polychaetes Paraprionospio pinnata, Magelona phyllisae, and Cossura chilensis, among others, and the amphipod Ampelisca araucana. However, the muddy shelf sediments are usually covered by dense mats of the giant sulphur bacterium Thioploca spp, especially off central and southern Peru (Fig. 4), where the oxygen deficiency is more intense (Gallardo 1977; Zafra et al. 1988; Arntz et al. 1991). The latitudinal distribution of Thioploca spp. ranges from $6^{\circ} \mathrm{S}$ to the central Chilean coast, coinciding roughly with the domain of the
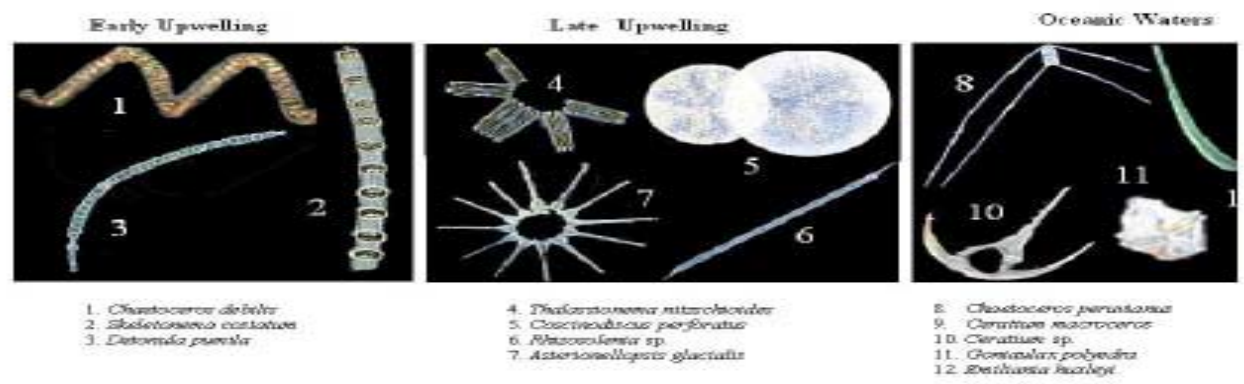

Figure 3. Dominant species during the successional stages of the phytoplankton community in the Peruvian coastal upwelling ecosystem: Early stages (recently upwelled waters); late stages (more stable conditions); and oceanic water stages.

FIGURA 3. Especies dominantes durante las etapas secuenciales de la comunidad fitoplanctónica en el ecosistema de surgencia de la costa peruana: Etapas tempranas (aguas recientemente surgidas); etapas tardes (condiciones más estables); y etapas de aguas oceánicas. 
Gayana 67(2), 2003

a)

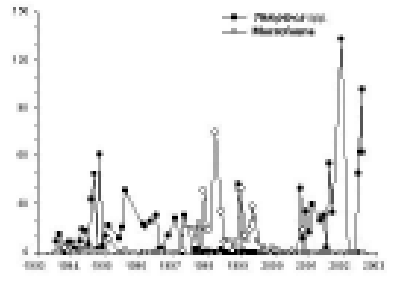

b)
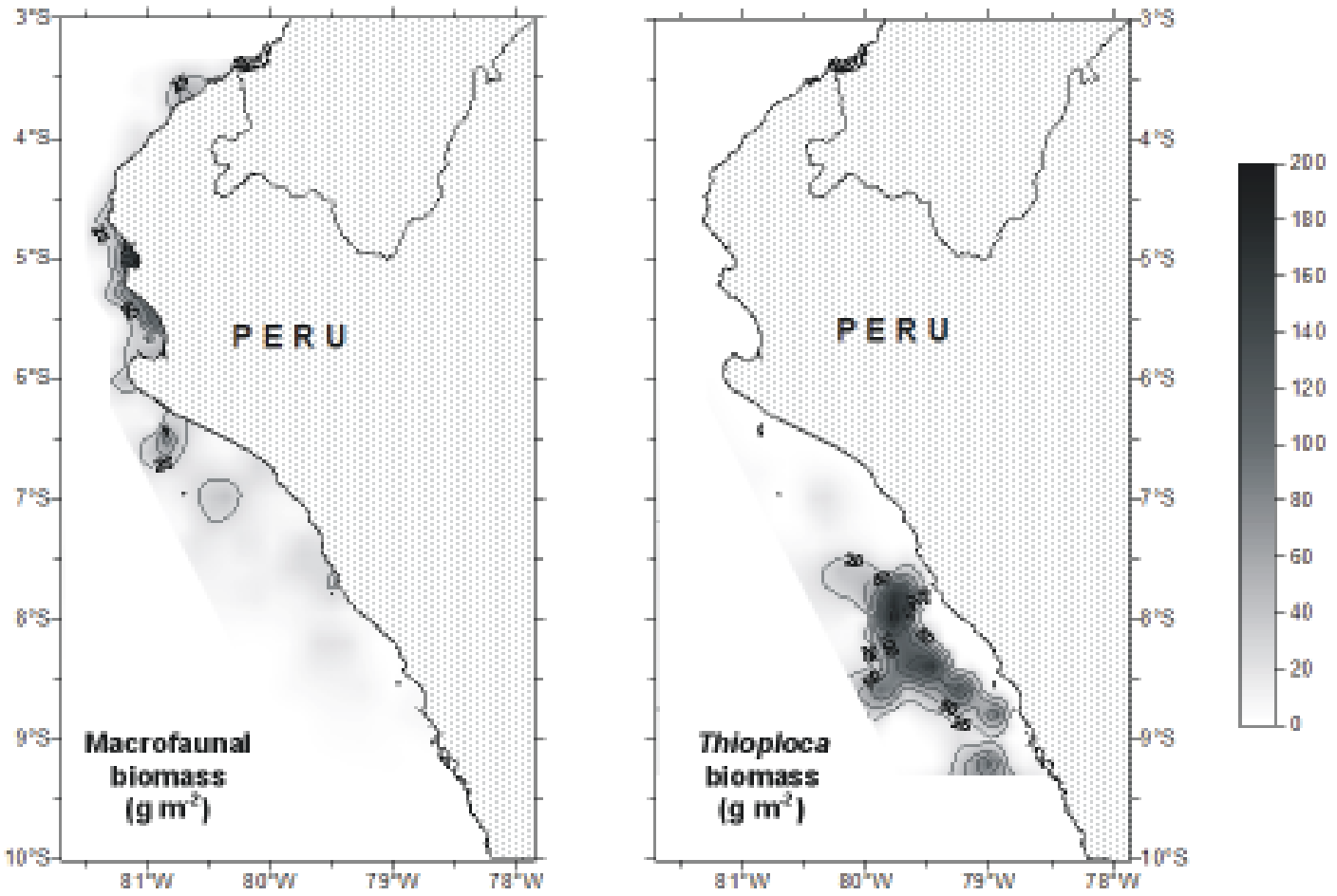

FIgURE 4. Temporal and spatial dominance of macrobenthos by macrofauna and Thioploca spp.: a) Biomass temporal variability off Callao (93 m depth); b) biomass distribution in 1989 spring, RV F. Nansen 1989-11/12 (D. Gutiérrez, unpub. data.).

FIGURA 4. Dominancia temporal y espacial del macrobentos por macrofauna y Thioploca spp.: a) Variabilidad temporal de la biomasa frente a Callao (93 m profundidad); b) Distribución de la biomasa en primavera de 1989, RV F. Nansen 1989-11/12 (D. Gutiérrez, datos no publicados). 
poleward Gunther undercurrent which is partially associated with the OMZ. off Callao, the biomass of Thioploca spp. surpasses that of the macrofauna during neutral and cold phases of the ENSO (Gutiérrez et al.2002). Within the core of the OMZ, the fauna are dominated by gutless, endosymbionthosting oligochaetes and high numbers of nematods and foraminifers, suggesting the evolution of a highly adapted community that profits from the large contents of relatively undergraded organic matter (Levin et al. 2001). At lower bathyal and abyssal depths, the macrobenthic biomass and diversity are enhanced due to the relatively high organic flux, compared to other benthic subsystems of the western hemisphere (Rowe 1971). Bathyal communities are also affected by high sediment instability caused by erosive processes (Levin et al. 2001).

\section{NeKTON}

This community sustains one of the largest fish standing stocks of the global ocean. The dominant pelagic upwelling species are the Peruvian anchovy
Engraulis ringens and the sardine Sardinops sagax. The former is closely associated with relatively cold, upwelled waters $\left(<17^{\circ} \mathrm{C}\right)$ and reached biomasses of up to 30 million tons before the 1971/1972 fishery collapse (Muck, 1989a; Csirke et al. 1996), while the latter attains its highest densities around the boundary between upwelled waters and oceanic waters. Further offshore $\left(>20^{\circ} \mathrm{C}\right)$ and along the shelf margin, the dominant species are the jack mackerel (Trachurus murphyi) and the chub mackerel (Scomber japonicus) (Muck 1989a). Mesopelagic species are largely dominated by lantern fish e.g. Vinciguerria lucetia (Tarazona \& Arntz 2001). Among the oceanic species are found the yellowfin tuna (Thunnus albacares) and the giant squid (Dosidicus gigas). The distribution of demersal nekton is also largely limited by oxygen deficiency (Muck 1989b; Espino \& Wosnitza-Mendo 1989). The most abundant demersal species is the Peruvian hake (Merluccius gayi peruanus), whose main area of distribution ranges from Ecuador to north central Peru (Chirichigno \& Cornejo 2001). Coastal nekton includes cusk-eels, flatfish, mullets, sea bass, rays and sciaenids, among others (Fig. 5).

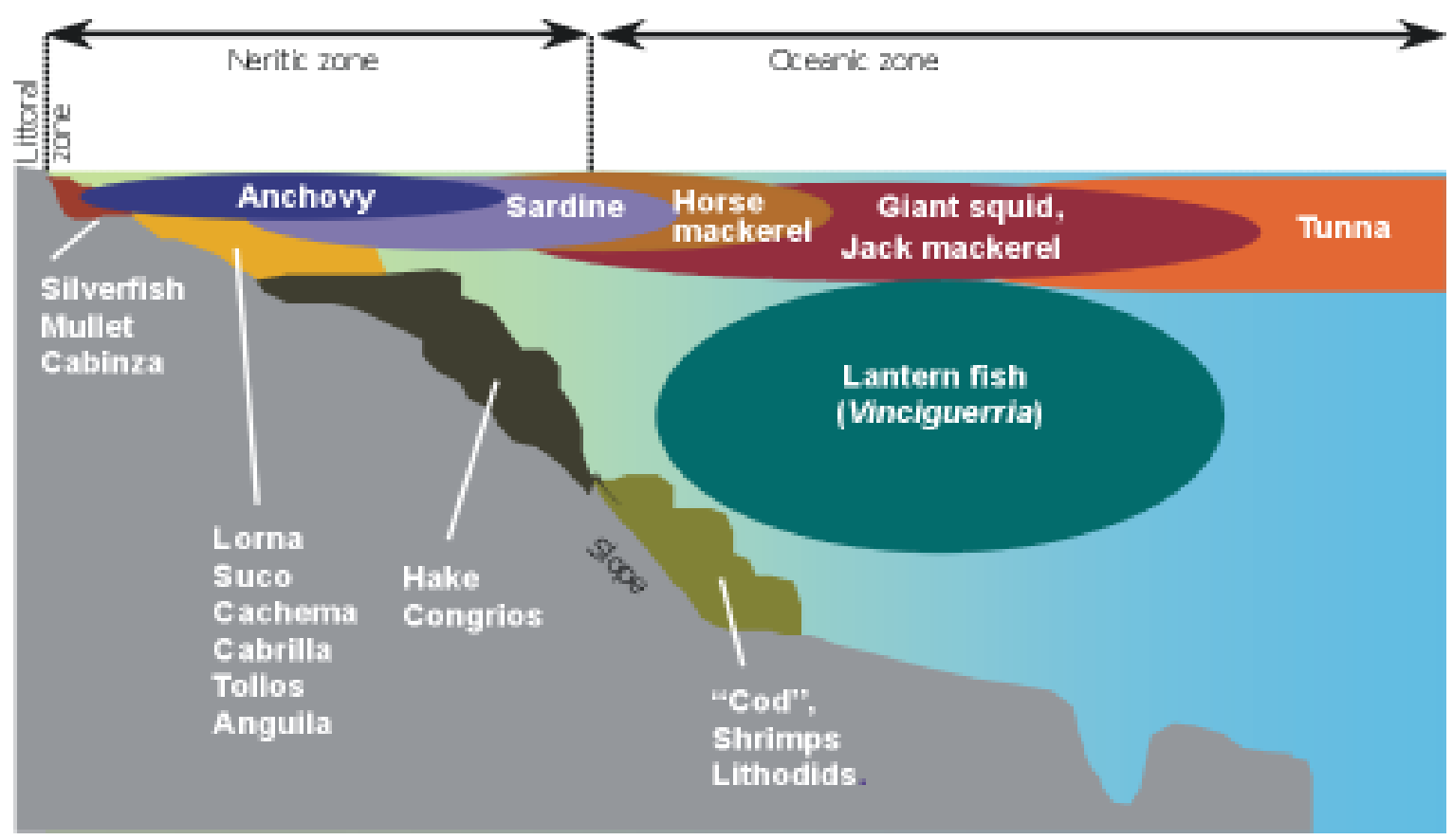

FIGURE 5. Distribution of main commercial species of nekton in the Peruvian coastal upwelling ecosystem.

FIGURA 5. La distribución de las principales especies comerciales de nekton en el ecosistema de surgencia de la costa peruana. 
Other marine fauna include birds of terrestrial origin, especially high populations of guano producers (Phalacrocorax bougainvillii, Sula variegata, and Pelecanus thagus) and others, and there are sea lions, fur seals, and several cetaceans (Murphy 1936; Jordán \& Fuentes 1966; Jahncke 1998; Majluf \& Reyes 1989). Seal and large whale populations were severely depleted, but are now legally protected.

\section{SOME TAXONOMICAL AND BIOGEOGRAPHICAL ASPECTS}

Table I summarizes the currently known number of families, genera, and species of the main marine fauna on and off the coast of Peru. The most studied taxonomical groups are Pisces with 1.070 species (Chirichigno \& Vélez 1998; Chirichigno \& Cornejo 2001); Crustacea, 480 species (especially Decapoda and Stomatopoda) (Chirichigno 1970; Del Solar et al. 1970; Del Solar 1972; Méndez 1981; Kameya et al. 1993); Mollusca 1.024 species (Alamo \& Valdivieso 1997; Paredes et al. 1998; C. Paredes, pers. comm.), and several groups of phytoplanktonic algae, 602 species (Ochoa et al. 1999 and references cited therein).

The total number of species that have been recorded is 3,638, but this should be taken as a minimum esti-

TABLE I. Preliminary numbers of marine families, genera, and species in the Peruvian coast.

TABLA I. Números preliminares de las familias, géneros y especies marinas en la costa peruana.

\begin{tabular}{|c|c|c|c|}
\hline Taxonomic Groups & Families & Genera & Species \\
\hline \multicolumn{4}{|l|}{ Algae } \\
\hline Bacillariophyta & 35 & 57 & 168 \\
\hline Pyrrophyta & 19 & 35 & 209 \\
\hline Chlorophyta & - & - & 37 \\
\hline Phaeophyta & - & - & 31 \\
\hline Rhodophyta & - & - & 157 \\
\hline Total & & & 602 \\
\hline \multicolumn{4}{|l|}{ Mollusca } \\
\hline Caudofoveata & 1 & 1 & 1 \\
\hline Solenogastres & 1 & 1 & 1 \\
\hline Polyplacophora & 5 & 12 & 34 \\
\hline Monoplacophora & 2 & 2 & 3 \\
\hline Gastropoda & 88 & 129 & 573 \\
\hline Bivalvia & 54 & 153 & 373 \\
\hline Scaphopoda & 2 & 3 & 3 \\
\hline Cephalopoda & 23 & 32 & 36 \\
\hline Total & & & 1024 \\
\hline \multicolumn{4}{|l|}{ Polychaeta } \\
\hline Errantia & 29 & 111 & 207 \\
\hline Sedentaria & 28 & 92 & 134 \\
\hline Total & & & 341 \\
\hline Brachiopoda & 2 & 2 & 2 \\
\hline \multicolumn{4}{|l|}{ Crustacea } \\
\hline Ostracoda: Myodocopa & - & - & 6 \\
\hline Cirripedia & - & - & 24 \\
\hline Isopoda & - & - & 18 \\
\hline Amphipoda & - & - & 18 \\
\hline Decapoda & 8 & 10 & 17 \\
\hline Stomatopoda & 67 & 208 & 397 \\
\hline Total & & & 480 \\
\hline Pisces & 194 & 549 & 1070 \\
\hline Aves & 14 & 30 & 82 \\
\hline Reptilia (Testudines) & 2 & 4 & 4 \\
\hline \multicolumn{4}{|l|}{ Mammalia } \\
\hline Cetacea & 7 & 20 & 30 \\
\hline Carnivora & 2 & 3 & 3 \\
\hline Total & & & 33 \\
\hline
\end{tabular}


mate, since several small taxonomical groups from zooplankton, foraminifers, etc. have not been included. The northern Peruvian coast shows a high biodiversity with a large number of species of Panamanian origin, due to the transition and mixing with water masses of equatorial and tropical origin; no species of subantarctic origin have been observed there. The relaxation of the oxygen deficiency also allows a larger number of fish, mollusks, and crustaceans to inhabit the continental shelf and upperslope sediments and the overlying waters. The presence of a transition zone from Caraquez Bay, Ecuador to Punta Aguja, Peru ( $\left.6^{\circ} \mathrm{S}\right)$ has been described by several authors (Dall 1909; Balech 1954; Koepcke 1957, 1958; Olsson 1961; Schweigger 1964; Medina 1969). Up to $50 \%$ of the recorded species are restricted to the transition zone between the PCUE and the Pacific Central American coastal ecosystem. Around $67 \%$ of the marine molluscs are restricted to the north of $6^{\circ} \mathrm{S}$ (Anadara spp., Pteria sterna, Ostraea spp., Chione subrugosa, Hexaplex sp., Melongena patula, and Atrina maura) (Paredes et al. 1998). A similar situation exists for crustaceans. Some of the most representative crustaceans of Panamanian origin found in the Peruvian northern region are Sicyonia disdorsalis, Farfatepenaeus spp., Xiphopenaeus kroyeri (continental shelf) and Nematocarcinus agassizii, Heterocarpus affinis, Hymenopenaeus doris (continental slope). With regard to Pisces, the families that are found only in the northern region are Pristigasteridae (4), Synoditidae (5), Triglidae (7), Centropomidae (6), Lutjanidae (7), Gobiidae (14), Achiriidae (6), Cynoglossidae (10), Balistidae (4), and Tetraodontidae.
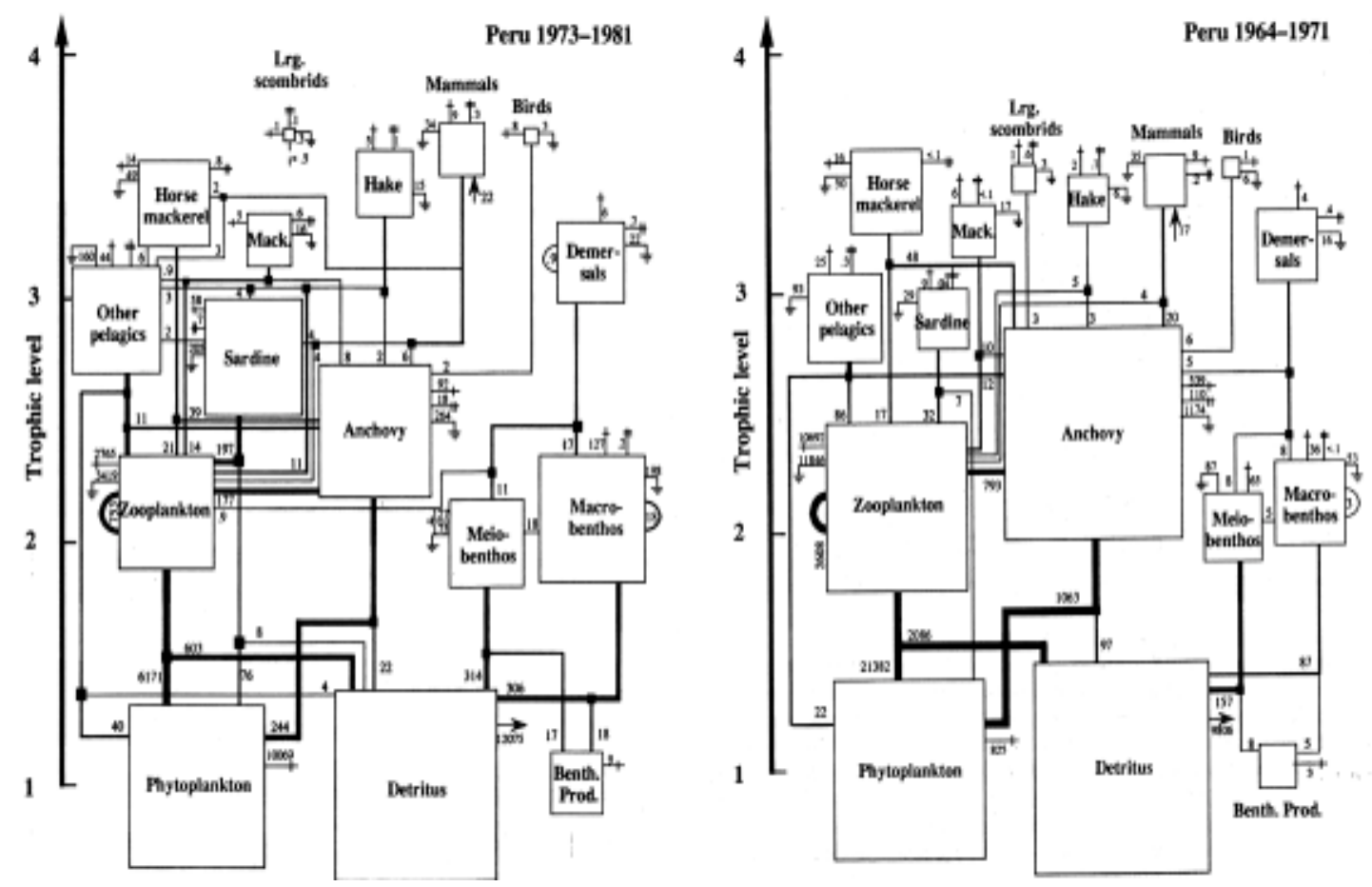

FIGURE 6. Mass-balance models of trophic structure of the Peruvian coastal upwelling ecosystem, before (19641971) and after (1973-1981) the anchovy collapse (from Jarre 1998).

Figura 6. Modelos de balance-masa de la estructura trófica de la anchoveta de surgencia de la costa peruana, antes (1964-1971) y después (1973-1981) del colapso del boquerrón (de Jarre 1998). 


\section{TROPHIC RELATIONSHIPS}

A number of studies have been made of the trophic relationships between Peruvian anchovy and other components of the ecosystem. It has been demonstrated that anchovy feed on zooplankton and on certain phytoplankton. Cannibalism is triggered by density-dependent interactions. Sardine consumes zooplankton and anchovy eggs. Jack mackerel and chub mackerel exert significant predation pressure on anchovy populations when oceanic waters approach the coast (e.g. during El Niño events). The same is true for hake, when oxygenated waters extend from north to south (Muck 1989b). Anchovy, in turn, exert a strong control on sardine and hake populations by feeding on their eggs (Espino \& Wosnitza-Mendo 1989; Muck 1989b). Most Peruvian guano birds, small cetaceans, and pinnipeds feed primarily on anchovy; other important predators are bonito (Sarda chilensis), sea lions, and fur seals (Muck 1989a).

Jarre et al. (1991, 1998) and Jarre (1998) investigated the ecosystem trophic structure by means of top-down, steady-state mass-balance models (Fig. 6). Mean transfer efficiency (from herbivores to top predators) was calculated to be 4$6 \%$. The whole of the production of the five dominant fish species (anchovy, sardine, chub mackerel, jack mackerel, and hake) is consumed in the following descending order of importance: by fish predators (jack mackerel, chub mackerel, hake, and other demersal species), fisheries, mammals, and other top predators (seabirds and other large pelagic fish) (Jarre et al. 1998). Compared with southern Benguela, zooplankton and macrobenthos have a lower impact on the trophic structure of the ecosystem (Jarre et al. 1998).

\section{INTERANNUAL VARIABILITY}

Among the major upwelling ecosystems, the PCUE is most subject to interannual variability (Brainard \& McLain 1987), due to ENSO and its warm (EN) and cold (LN) phases (Carr 2002). With the former, disturbances in the pressure field of the equatorial Pacific, which are associated with the weakening or reversal of trade winds, trigger the propagation of Kelvin waves to the eastern Pacific. These cause an increase in sea level and the deepening of the thermocline, oxycline, and nutricline. However, coastal winds tend to be stronger south of $5^{\circ} \mathrm{S}$, increasing sea roughness, turbulence, and mixing; these winds may result from the maintenance of the sea-land pressure gradient due to local changes of land insolation (Enfield 1981; Mendo et al. 1987; Pizarro 1988). The upwelling can become even more intense but it does not bring nutrient-rich waters to the surface and primary production decreases significantly (Barber \& Chávez 1983). At the same time, tropical and equatorial surface waters are displaced to the south; the latter may reach the central coast during the strongest EN events. The saline and warm oceanic waters can also intrude as far as the coast (Guillén et al. 1985; Sánchez et al. 2000). The decrease of primary production, the deepening of the thermocline, and the transient enhancement of the Peruvian undercurrent contribute to the deepening of the OMZ, down to $200 \mathrm{~m}$ in 1982/1983 and to $250 \mathrm{~m}$ in 1997/1998 (Guillén et al. 1985; Arntz \& Fahrbach 1991; Sánchez et al. 2000). The intrusion of tropical, equatorial, and oceanic waters to the south and east, the decrease of fertility, and the deepening of the OMZ are the main oceanographic disturbances that affect the biological communities of the PCUE. Primary production is reduced by $50 \%$ and the phytoplankton community becomes dominated by oceanic and equatorial dinoflagellates and large diatoms (Chávez et al. 1989; Ochoa et al. 1985; Rojas de Mendiola et al. 1985). Local phytophagous zooplankton are partially replaced by carnivorous species associated with warm waters (Tarazona \& Arntz 2001). Among the main biological indicators of the water masses associated with EN events are the dinoflagellates Ceratium breve (surface equatorial water) and Ceratium praelongum, C. incisum and C. extensum (surface subtropical water) (Ochoa et al. 1985). The copepod, Centropages furcatus, which is an indicator of surface equatorial water, is also a biological indicator of EN (Carrasco \& Santander 1987). Off central Peru, increases in oxygen near sublittoral bottoms favors an increase in the diversity and biomass of macrofaunal species but is unfavorable for Thioploca mats (Arntz et al. 1991; Gutiérrez et al. 2002). Macrofaunal interface-feeders are replaced by a predominance of 
subsurface feeders and stronger bioturbators (Gutiérrez et al. 2002). Warm water invertebrates such as shrimps, swimming crabs, and molluscs migrate from tropical areas (Arntz \& Fahrbach 1991; Tarazona \& Arntz 2001). In addition, a large number of tropical and oceanic fish invades the neritic zone. A sample list of these species is given in Tarazona \& Arntz (2001). Strong EN events are detrimental to anchovy. Sardine, jack mackerel, and chub mackerel approach the coast yielding higher landings. The population of hake is favored by the improved oxygen conditions, but fish catches are, in general, reduced due to the dispersal of the populations and their lower catchability.

\section{DECADAL VARIABILITY AND GLOBAL CHANGE}

Regime shifts in the upwelling ecosystems appear to occur on a decadal scale. Off Peru, anchovy and sardine have alternated as dominant species of the pelagic subsystem (Chávez et al. 2003). Two regime shifts have been recognized, the first around 1971, when the anchovy population collapsed and sardine population levels began to increase steadily until the mid-1980s, and the second, in the early 1990s, when anchovy recovered its dominant position in the pelagic domain. Jarre (1998) and Jarre et al. (1998) modelled the trophic structure of the ecosystem before (1964-1971) and after (1972-1981) the collapse of the anchovy population. Among the most relevant findings was that anchovy became scarce due to the decrease in the zooplankton standing stock (Carrasco \& Lozano 1989) and this could be explained by increased predation pressure by jack mackerel and chub mackerel (Fig. 6). Other important changes were the increase in mammals, birds, and hake as they partly switched from anchovy to sardine and predatory fish (Jarre 1998). Information about decadal changes in the biodiversity of the PCUE is, however, still limited; possible changes in the composition of the plankton and benthic communities have not been assessed, nor have changes in geographical distribution. Similarly, the problem of the interaction of global climate change and the structure and dynamics of the ecosystem has not been studied. Time-series data of alongshore wind stress indicate an intensification, at least during the past 50 years (Chávez et al. 1989; Jahncke, in prep.). However, a parallel deepening of the thermocline may have diminished the effect of increased upwelling on fertility and new production (Chávez et al. 1989). On the other hand,

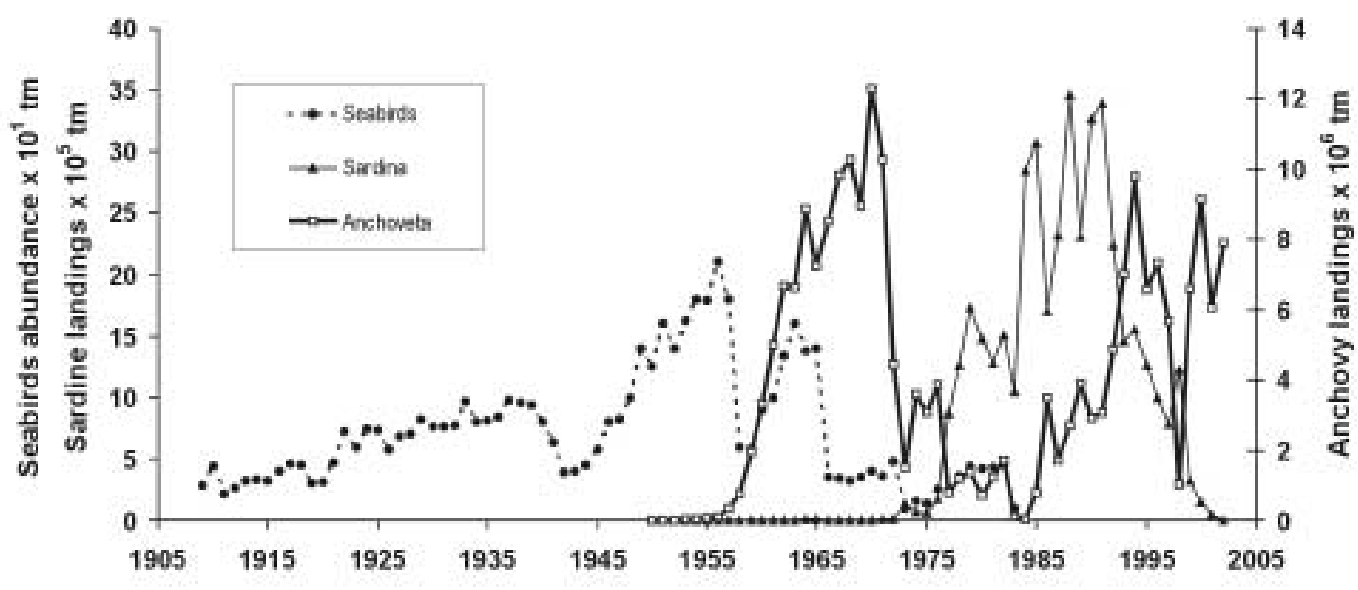

FIGURE 7. Long-time variability of seabird abundance, and anchovy (Engraulis ringens) and sardine (Sardinops sagax) landings from Peru.

FIGURA 7. La variabilidad, a través del tiempo, de la abundancia de aves guaneras, y la captura de anchoveta (Engraulis ringens) y sardina (Sardinops sagax) en Perú. 
a possible deepening of the upper boundary of the $\mathrm{OMZ}$ (which is related to the $15^{\circ} \mathrm{C}$ isotherm) could have affected the vertical and horizontal distribution of several planktonic, nektonic and benthic species in the long-term (Fig. 7).

\section{THE NEARSHORE AREAS}

Environmental setting

This subsystem is defined as the zone located between the high water mark and a depth of ca. 30 to $40 \mathrm{~m}$ (corresponding to the photic zone) off the coast, south of $5^{\circ} \mathrm{S}$. Biological communities are strongly influenced by the particular characteristics of the substrate, by the interaction with the open ocean, and by the impact of fisheries and other anthropogenic activities that damage the integrity of the ecosystem. The shallow coastal areas are also affected by hypoxia events and by oceanographic changes associated with EN (Fig. 9). Temperature and the dissolved oxygen concentration decrease latitudinally from north to south. Coastal waters are relatively cold due to upwelling, fluctuating from $13^{\circ}$ to $23^{\circ} \mathrm{C}$ between winter and summer, respectively (Tarazona \& Arntz 1986; Arntz et al. 1991). Salinity only varies significantly during EN when oceanic waters approach the coast (Tarazona et al. 1985). Dissolved oxygen near the bottom diminishes rapidly with depth leading to hypoxia $\left(<1 \mathrm{ml} \mathrm{l}^{-1}\right)$, even at depths shallower than $20 \mathrm{~m}$ (Rosenberg et al. 1983). The oxygen concentration varies according to the degree of coastal exposure and the local water circulation, being higher when currents are stronger (Independencia Bay) and reduced or absent when there is stagnation (Ancon Bay). Bottom water hypoxia is also present in polluted areas, e.g. the bays of Ferrol and Samanco. Long sections of the coast under nearly anoxic conditions, sometimes releasing hydrogen sulphide, have been observed off central and southern Peru. This promotes the development of filamentous bacterial communities of the genus Beggiatoa in shallow soft bottoms and of the genus Thioploca in deeper areas of nearshore and bays.

\section{DIVERSITY}

Two rocky intertidal mytilid communities have been described. The Perumytilus purpuratus community is comprised of 87 species and that of Semimytilus algosus, of 77 species (Paredes \& Tarazona 1980). On subtidal bottoms, kelp forests of Macrocystis pyrifera, M. integrifolia, and Lessonia trabeculata are present along the central and southern Peruvian coast (Fig. 8). These macroalgae provide a habitat for highly diverse assemblages; Lessonia trabeculata, for example, has 143 associated species with a mean $\log _{2}$ diversity of 3.5 bits per rhizoid (Romero et al. 1988; Fernández et al. 1999).

For common subtidal rocky bottoms, 119 species have been recorded. However, the subtidal hardbottom community of the mussel Aulacomya ater hosts a macrofaunal assemblage of 186 species (Soenens 1985; Paredes et al. 1988).

The diversity of soft-bottom communities is mainly explained by polychaetes (Fig. 9), especially in hypoxic areas (Tarazona et al. 1998). Comparing the variability of the macroinfauna of Ancon Bay and Independencia Bay (<50 m), Tarazona et al. (1991) found a lower richness in the former (0-16 vs. 6-58) at similar depths. In the water column, the phytoplankton is dominated by diatoms and the species composition changes with oceanographic variability. Typical diatom species are Skeletonema costatum, Thalassionema nitzschoides, Chaetoceros sociales, Pseudo-nitzschia delicatissima, and Ch. curvisetus, which can attain dominances of more than $99 \%$. Typical dinoflagellate species are Gymnodinium sanguineum and Prorocentrum micans, which can reach represent up to ca.9\% of the phytoplankton population (Ochoa et al. 2000; Sánchez et al. 1988). A lower phytoplankton $\log _{2}$ diversity has been observed in Ancon Bay (2.5 bits cell $\left.{ }^{-1}\right)$ than in Independencia Bay (2.7-4.0 bits cell ${ }^{-1}$ ) due to the frequent blooms of upwelling species in the former case (Sánchez et al. 1988; Ochoa \& Gómez 2000). The ichthyofauna, which diminish rapidly below $30 \mathrm{~m}$ depth due to oxygen deficiency, are characterized by a high diversity of sciaenids ("ayanque" Cynoscion analis, "cabinza" Isacia conceptions, "lorna" Sciaena deliciosa, etc.), and flatfish ("lenguado", Paralichthys adspersus), rays (Myliobatis spp.), mullets (Mugil cephalus, M. curema), and others (Arntz \& Tarazona 1990). 
Marine biodiversity in Perú: TARAzona, J. ET AL.

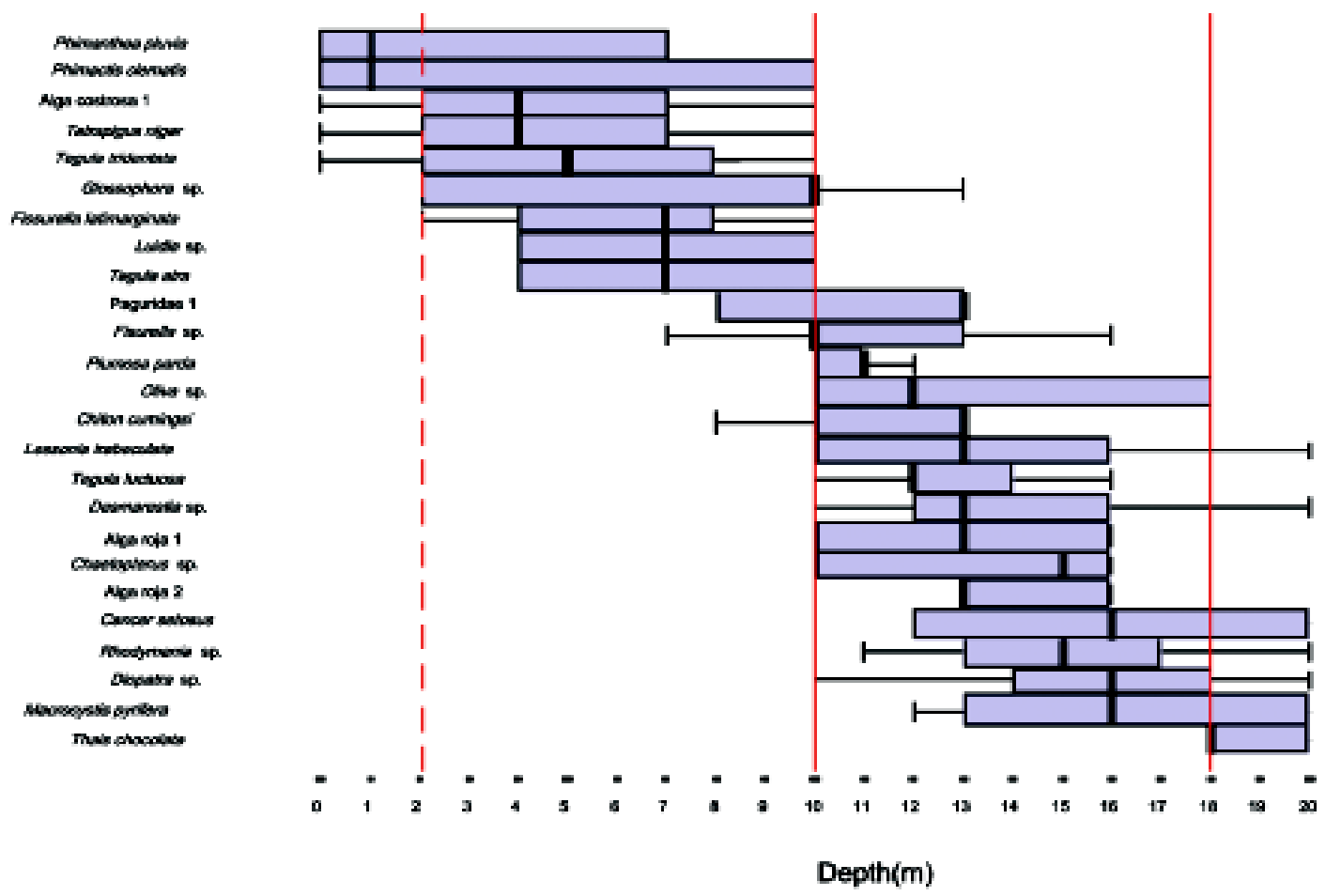

FIGURE 8. Zonation and vertical distribution of hard bottom macrobenthos in Independencia Bay, Peru.

FIGURA 8. La zonación y distribución vertical del macrobentos de fondos duros en la bahía de Independencia, Perú.
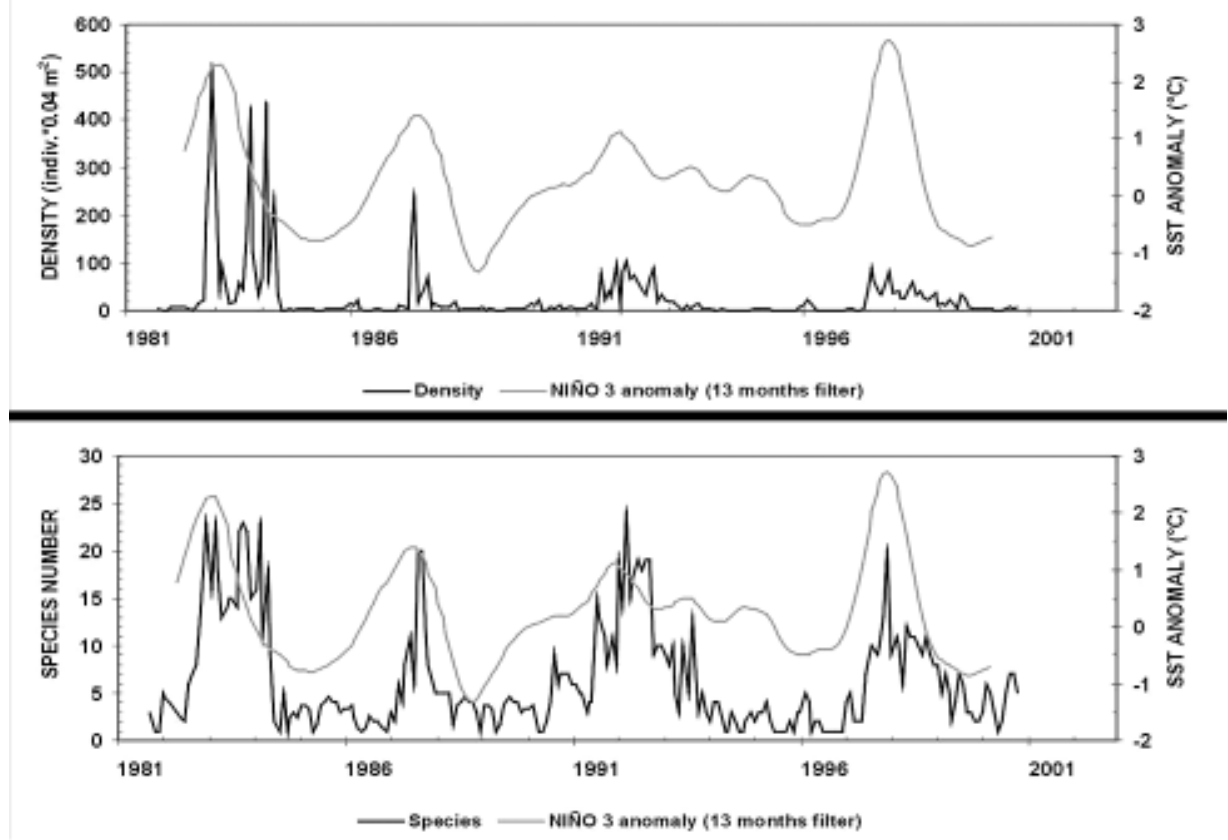

FIGURE 9. Number of species and density of the macrobenthos community in Ancon Bay, related to El Niño 3 temperature anomalies, $1981-2000$.

FiguRA 9. El número de especies y la densidad de la comunidad macrobéntica en la bahía de Ancon, relacionados con las anomalías de temperatura del Niño 3, 1981-2000. 
INTERANNUAL VARIABILITY

The interannual variability of oceanographic conditions (from EN to LN) triggers a number of changes in biological communities. The succession in the phytoplankton was described earlier (see Plankton communities). In the intertidal zone, the macroalga, Chondracanthus chamissoii, increased its density from 100 ind. $32 \mathrm{~m}^{-1}$ in 1996 to 2,684 ind. $32 \mathrm{~m}^{-1}$ in October 1997, during the $1997 / 1998$ early EN (Tarazona et al. 1999). The populations of Lessonia trabeculata can attain densities of 5 ind. $\mathrm{m}^{-2}$ during non-EN years, but are totally depleted during EN events (Fernández et al. 1999; Fernández $\&$ Tarazona 2000). The latter also occurs with other macroalgae such as Macrocystis pyrifera and Rhodymenia flabellifolia. The speed of the recovery process of the kelp populations depends on the environmental conditions following EN (Fernández et al. 1999, 2002). For invertebrates, the reproductive and larval recruitment processes are affected positively or negatively, varying from case to case. The Aulacomya ater community, which during normal years reaches a biomass of up to $40 \mathrm{~kg} \mathrm{WW} \mathrm{m}^{-2}$ and an average density of 1650 ind. $\mathrm{m}^{-2}$, is severely reduced during EN down to 25 ind. $\mathrm{m}^{-2}$ (Valle et al. 2002). The scallop Argopecten purpuratus, on the other hand, shows low average densities during nonEN years (0.85 ind. $\mathrm{m}^{-2}$ for 1995-1997), but increases significantly during EN, attaining maximal densities during the post-EN periods (183.5 ind. $\mathrm{m}^{-2}$ and $5.25 \mathrm{Kg} \mathrm{WWm}^{-2}$ in 1985) (Mendo et al. 1988). This response of the scallop to EN events is related to changes in fecundity, larval growth period, and predation pressure, all of which favor an increase in larval recruitment (Vargas et al. 1988; Ramos et al. 1999; Ishiyama \& Shiga 1998; Talledo et al. 1986). The density and biomass of macrofaunal communities in normally oxygen-deficient soft bottoms also show a high interannual variability, ranging from 225 ind. $\mathrm{m}^{-2}$ and $7 \mathrm{mg} \mathrm{AFDWm}{ }^{-2}$, during non-EN years, to values of 4275 ind. $\mathrm{m}^{-2}$ and $2271 \mathrm{mg}$ $\mathrm{AFDWm}^{-2}$ during EN; the number of species also increases 3-4 fold during EN. High mortalities of local benthic invertebrates (crabs, clams, sea urchins, etc.) are observed when warm waters intrude to the coast during EN but, equally, the immigrant warm water invertebrates do not persist when cold waters return (Arntz et al. 1985; Tarazona et al. 1998). In turn, LN periods favor the recruitment of Aulacomya ater, Semimytilus algosus, and the bivalve, Hiatella solida, but affect negatively the recruitment of $A$. purpuratus (Ramos et al. 2000).

\section{TROPHIC RELATIONSHIPS}

Studies on trophic relationships in shallow coastal areas are scarce. Soft-bottom macrobenthic assemblages have been grouped into deposit-feeders, carnivores/scavengers, suspension feeders, and chemolithotrophs (e.g. Beggiatoa) (Tarazona et al. 1991). A change in the trophic structure of shallow water ichthyofauna during EN has also been reported, with a tendency to an increase in benthophagous fish and a reduction in the availability of the main prey species (Hoyos et al. 1985).

\section{ANTHROPOGENIC IMPACTS}

There is increasing human activity in shallow Peruvian coastal areas. Some environmental impact studies have been carried out in bays, such as Paita, Carquín-Huacho, Callao, Huarmey, and Ferrol (Chimbote) that are subject to significant organic loads. The latter is the most polluted and has an anoxic bottom (Sánchez et al. 1996; Guzmán et al. 1997; Orozco et al. 1997; Jacinto et al. 1997). Macrobenthic communities in these bays have lower abundances and diversities and different species compositions from those in unpolluted situations. Chemical contamination (e.g. copper) is also present in some bays, such as Callao (Valle 1998). Bioassays to determine the effect of certain toxic anthropogenic effluents on marine invertebrates have been carried out (Sánchez et al. 1988; Vera et al. 2001; Tam et al. 2002).

\section{THE MANGROVE ECOSYSTEM}

\section{General characteristics}

In Peru, the main distribution area is from the limit with Ecuador, the mouth of the Zarumilla river (Punta Capones $3^{\circ} 24^{\prime} \mathrm{S}$ ), to $8 \mathrm{~km}$ south of the Tumbes River (southern Corrales inlet, $3^{\circ} 34^{\prime} \mathrm{S}$ ), the forest covering approximately 6.250 ha. A possible relict of the past extension of mangrove forests with an area of 300 ha is also present 
$350 \mathrm{~km}$ south, at the mouth of the Piura River (5'32’30" S).

In total, the mangrove ecosystem covers almost 0.01 percent of the Peruvian mainland. There is an increasing interest in its conservation and management. The government created the Tumbes Man- grove National Sanctuary in 1988. Currently, public institutions and NGOs are coordinating management actions. The existing knowledge about the biodiversity of the flora and fauna associated with the Peruvian Mangrove ecosystem is summarized in Table II.

TABLE II. Preliminary numbers of families, genera, and species of the mangrove ecosystem in northern Peru.

TABLA II. Números preliminares de familias, géneros y especies del ecosistema de mangles al norte de Perú.

\begin{tabular}{|c|c|c|c|}
\hline Taxa & Families & Genera & Species \\
\hline \multicolumn{4}{|l|}{ FAUNA } \\
\hline \multicolumn{4}{|l|}{ Chordata } \\
\hline - Birds & 44 & 95 & 117 \\
\hline - Fishes & 41 & 74 & 102 \\
\hline - Mammals & 9 & 12 & 12 \\
\hline - Reptiles & 8 & 11 & 12 \\
\hline - Amphibia & 1 & 1 & 1 \\
\hline - Urochordates & 1 & 1 & 1 \\
\hline - Cephalochordates & 1 & 1 & 1 \\
\hline \multicolumn{4}{|l|}{ Hemichordata } \\
\hline - Enteropneusts & 1 & 1 & 1 \\
\hline \multicolumn{4}{|l|}{ Arthropoda } \\
\hline - Crustaceans & 20 & 39 & 61 \\
\hline - Chelicerates & 1 & 1 & 1 \\
\hline \multicolumn{4}{|l|}{ Mollusca } \\
\hline - Bivalves & 26 & 42 & 84 \\
\hline - Gasteropods & 25 & 44 & 72 \\
\hline - Cephalopods & 1 & 1 & 1 \\
\hline - Polyplacophora & 1 & 1 & 1 \\
\hline \multicolumn{4}{|l|}{ Annelida } \\
\hline - Polychaetes & 17 & 24 & 25 \\
\hline \multicolumn{4}{|l|}{ Echinodermata } \\
\hline - Stelleroidea & 3 & 3 & 3 \\
\hline - Echinoidea & 2 & 2 & 2 \\
\hline Sipunculida & 1 & 1 & 1 \\
\hline Priapulida & 1 & 1 & 1 \\
\hline Phoronida & 1 & 1 & 1 \\
\hline Nemertina & 1 & 1 & 1 \\
\hline Brachiopoda & 1 & 1 & 1 \\
\hline Cnidaria & 2 & 2 & 2 \\
\hline \multicolumn{4}{|l|}{ Flora } \\
\hline Cryptogama & 1 & 1 & 1 \\
\hline Phanerogama & 23 & 36 & 51 \\
\hline
\end{tabular}

\section{DIVERSITY OF MANGROVE FLORA}

Five species of mangrove trees have been recorded. Rhizophora mangle, the dominant species, and $R$. harrisonii are only found in the main Tumbes area, which is also the meridional limit of the genus.
Avicenia germinans, which is more tolerant of suboptimal temperatures, is present in Tumbes and in the Piura River relict area. The other two species, Laguncularia racemosa and Conocarpus erectus, attain lower densities and are distributed above the high water. In the Tumbes mangrove area, 52 spe- 
cies of plants, grouped in 24 families have been recorded. Among the most common are Prosopis chilensis, Acacia macracantha, and Scutia spicata, which form small bushes within the mangrove forest. In open areas, within and along the mangrove boundaries, sea-grasses develop; typically, these are species such as Eraglostis amabilis, Bouteloua disticha, Sporobolus piramidatus, Cacabus prostatus, Batis maritima, Sesuvium portulacas-trums and Pectis arenaria. A high density and high diversity have been observed in the plankton of the estuarine waters, but systematic reports are lacking (W.W.F. 1986).

Diversity of mangrove fauna

The inlets are inhabited by a rich diversity of fauna, some being permanently present, others temporarily. The ichthyofauna are composed of 102 species grouped in 41 families. Several marine fish species, enter the inlets for feeding, spawning, or shelter purposes, seasonally or even sporadically. The main fish found in the Tumbes mangrove area are: "liza" Mugil curema, "bagre" Galeichthys jordani, "tamborin" Sphoeroides annulatus, "periches" Diapterus peruvianus and Gerres cinereus, "Roncador" Pomadasys branicki, "peje brujo" Daector dowi, "gobios" Bathygobius spp., and "lenguados" Citarychthys gilberti and Achirus acutum. Species diversity is lower in the summer than during the winter, most of the inlet ichthyofauna then being composed of juveniles.

Crustaceans are a very important group in the mangrove ecosystem. Juveniles of the shrimps Penaeus stylirrostris, $P$. vannamei, and $P$. occidentalis are found within the tidal channels; the subtidal benthos includes Squilla spp. and the swimming crab, Callinectes spp. The muddy areas are home to several amphibious, tide-dependent, burrowing crabs: Ucides occidentalis, Cardisoma crasus, Uca princeps, Uca panamensis, Uca insignis, and Uca galapagensis. Other crab species such as Aratus pisoni, Goniopsis pulchra, and Pachigrapsus transversus are found moving on the aerial roots and on the leaves (Peña 1976).

Around 117 species of birds are associated with the mangrove ecosystem in Peru. Some terrestrial species also spend part of their life cycles in the mangrove forest. There have been no studies devoted specifically to the mammals and reptiles of the
Tumbes mangroves. Recorded mammal species number 12, grouped in 9 families, while there are 12 recorded species of reptiles grouped in 8 families.

Other aspects

Knowledge about the functioning of the ecosystem is scarce or non-existent. Population dynamics, trophic relationships, energy budgets, biogeochemical fluxes, ecosystem modelling, etc., have yet to be studied. Similarly, there are no time series data on ecological or physical-chemical parameters of the Peruvian coastal mangrove ecosystem.

\section{CONSERVATION AND MANAGEMENT}

Peru is a signatory of several international agreements concerned with the protection of marine ecosystems, and of migratory species. By virtue of these, the Peruvian state is committed to protect the fragile ecosystems in marine and coastal environments. The National Strategy for Biological Diversity (ENDB) gives priority to developing protocols for the sustainable management of natural resources in order to mitigate the negative impacts of the anthropogenic activities which are not compatible with the objective of the conservation of biodiversity in the long-term.

The country has a National System of Protected Natural Areas (SINANPE). These are continental and marine domains established to conserve their biodiversity, landscape, and other features of scientific interest that will aid the sustainable development of the country. Currently, only one marine protected area has been created, but five others have been proposed. Additionally, the Special Project for the Promotion of the Use of Guano Coming from Sea Birds (PROABONOS), which is administered by the Ministry of Agriculture, aims to protect marine islands and capes, forbidding fishing activity within $50 \mathrm{~m}$ of the shore line.

\section{RESEARCH RESOURCES}

In general, institutional capacity for work on biodiversity is restricted by a shortage of personnel and the limited facilities in laboratories and coastal 
research stations. The number of highly qualified scientists is insufficient to fulfill the requirements for research on marine biodiversity in the country (Table III), and, in most cases, instrumentation is scarce and obsolete and modern techniques in molecular biology, genetics, and oceanography are little used. However, some research groups have made significant achievements which are noteworthy.

Although marine microbiology (bacteria and fungi) is not, in general, well developed in Peru due to the lack of human and technological resources, the laboratory of Environmental Microbiology and Biotechnology of the San Marcos University (UNMSM) has established a collection of around 200 strains of marine bacteria isolated from sea water, sediments, and certain organisms (mainly fish and benthic invertebrates) of the Peruvian coast; some of the strains have been found to produce inhibitory substances, enzymes, and antibiotics. The research lines are still in their early stages but the identification and characterization of marine microorganisms of biotechnological importance and those producing probiotic agents is already underway.

In the field of research on plankton, the Instituto del Mar del Perú (IMARPE), the UNMSM and San Agustín University (UNSAA) are developing traditional lines of investigation such as the monitoring of water mass indicator species, the study of red tides and phytoplankton potentially toxic to filterfeeding organisms, and the assessment of the spatial and temporal distribution of ichthyoplankton.

The better developed research programs involving molluscs, crustaceans, echinoderms, and fish are concerned with taxonomy, biogeography, and the population ecology of certain species of commercial importance. At the present time, many of the specialists in this area have emigrated or retired. The research groups with the longest experience are in IMARPE and UNMSM.

Research on polychaetes, foraminiferans, and other invertebrates is restricted by a shortage of specialists and limited to taxonomic and biogeographical aspects. The most important collection is in UNMSM.

Turtles, birds, and marine mammals are being studied by a considerable number of research groups due to the participation and greater support of the non-governmental organizations dedicated to conservation. The main lines of investigation are: population ecology, conservation, interaction with fish- eries, trophic ecology and reproductive biology. A large amount of work is currently being carried out on the population ecology, of pelagic fish. This has resulted in some notable achievements.

Research at the ecosystem level also lacks infrastructure, equipment, and human resources. The major advances made so far are in long time data series for intertidal and shallow water benthic communities, and the interactions of anchovy with the pelagic subsystem.

TABle III. Preliminary list of specialists in marine biodiversity from Peru.

TABLA III. Lista preliminar de los especialistas en la biodiversidad Marina en Perú.

\section{TOPICS OF TAXONOMY}

BACTERIA AND FUNGI

Débora Alvarado (UNMSM)

Jorge León (UNMSM)

Wilbert Serrano (UNMSM)

Germán Vergaray (UNMSM)

Macroalgae

César Acleto (Museo de Historia Natural Javier Prado)

Phytoplankton

Emira Antonietti Villalobos (IMARPE)

Flor Chang Loo Kung (IMARPE)

Elcira Delgado Loayza (IMARPE)

César Fernández Ojeda (IMARPE)

Olga Gómez Caballero (UT Callao)

Noemí Ochoa López (UNMSM)

Blanca Rojas de Mendiola (IMARPE)

Sonia Sánchez Ramírez (IMARPE)

Patricia Villanueva Merino (IMARPE)

Amparo Vizcarra (UNSAA)

ZOOPLANKTON

Katia Aronés (IMARPE)

Patricia Ayón (IMARPE)

Sulma Carrasco (IMARPE)

Margarita Girón (IMARPE)

Olga Gómez (UT Callao)

Roberto Quesquén (IMARPE)

Olinda Sandoval (IMARPE)

Polychaeta

Elba Canhuire (UNMSM)

Juan Tarazona (UNMSM)

Crustacea

Albertina Kameya Kameya (IMARPE) 
Matilde Méndez Guerrero (particular)

Leonardo Romero (UNMSM)

Mollusca

Víctor Alamo (URP)

Franz Cardoso (UNMSM)

Pedro Huamán (UNMSM)

Aldo Indacochea (CONCYTEC)

Valentín Mogollón (UNFV)

Carlos Paredes (UNMSM)

Mario Peña (particular)

Víctor Rivadeneira (URP)

Violeta Valdivieso (FONDEPES)

ECHINODERMATA

Yuri Hooker Mantilla (IMARPE)

Jorge Zeballos Flor (IMARPE)

OTHERS INVERTEBRATES

Sergio Mayor (U. Concepción)

Carlos Paredes (UNMSM)

PISCES

Norma Chirichigno Fonseca (UNFV)

Yuri Hooker Mantilla (IMARPE)

Luis Hoyos (UNMSM)

Juan Vélez Diéguez (U.T. del Callao)

Aves

Aquiles García-Godos (IMARPE)

Elisa Goya Sueyoshi (IMARPE)

Jaime Jahncke (IMARPE)

Rómulo Jordán (CONCYTEC/UNMSM)

José Carlos Márquez (IMARPE)

Luis Paz Soldán (Particular)

Juan Carlos Riveros (WWF)

Raúl Sánchez (GEA Perú)

Carlos Zavalaga (U. California)

RePtilia (TESTUdines)

Joanna Alfaro (Asociación pro Delphinus)

Elisa Goya (IMARPE)

Camelia Manrique (APECO)

Nelly de Paz Campos (ACOREMA)

Cecilia Rivas (GEA Perú)

Ximena Vélez (APECO)

Mammalia

Milena Arias-Schreiber (IMARPE)

Robert Clarke (particular)

Mónica Echegaray (ACOREMA)

Aquiles García-Godos (IMARPE)

Patricia Majluf (WWF)

Obla Paliza (particular)

Julio C. Reyes (ACOREMA)

Koen Van Waerebeed (CEPEC)

TOPICS OF COMMUNITY ECOLOGY

Wilmer Carvajal (IMARPE)
Oscar Guillén (UNMSM)

Dimitri Gutiérrez (IMARPE)

Jaime Jahncke (IMARPE)

Miguel Lleelish (INRENA)

Miguel Niquén (IMARPE)

Mario Peña (particular)

Leonardo Romero (UNMSM)

Sonia Sánchez (IMARPE)

Juan Tarazona (UNMSM)

Sonia Valle (CICESE)

TOPICS OF POPULATION ECOLOGY \& FISHERIES

Jorge Csirke (FAO)

Marco Espino ( IMARPE)

Renato Guevara (IMARPE)

\section{CURRENT UNKNOWNS IN MARINE BIODIVERSITY RESEARCH}

\section{TAXONOMY}

Current knowledge about the diversity of zooplankton, molluscs, echinoderms, and the taxa of other small invertebrates is scant for the transition zone within the Pacific Central American Coastal Ecosystem. Most of what is known about the biodiversity of crustaceans comes, in fact, from the northern zone of the Peruvian coast, a lower effort having been devoted to the zone south of $6^{\circ} \mathrm{S}$. Some of the most poorly studied groups are most types of microbial organisms (heterotrophic and chemolithotrophic bacteria, cyanobacteria, fungi, etc.), marine plants, and small invertebrate phyla (Table I). Truly systematic studies are scarce for the majority of the taxonomical groups. Studies of biogeography and evolutionary relationships are almost non-existent. In the case of large vertebrates, there is a lack of knowledge about their behavior, migration routes, population dynamics, and genetic variability. The biodiversity of parasites is largely unknown.

\section{ECOSYSTEM STUDIES}

Among benthic communities, the meiofauna and the microfauna have yet to be studied. Zooplankton communities also await attention. Trophic studies are, in general, scarce, especially in nearshore areas. The physiology and reproductive cycles of invertebrates are similarly unknown. On a broader 
scale, the spatial and temporal variability of biological communities and system processes are not well understood due to insufficient oceanographic data at a mesoscale level. More information about the biota associated with the OMZ (both in the water column and the sediments), the bathypelagic and abysopelagic communities, and the offshore (> 100 $\mathrm{km})$ pelagic communities is required. The patterns of migration of fish and large vertebrates associated with oceanic waters are still poorly known. Furthermore, even though the effects of EN on the distribution and standing stocks of several species of economic importance have been studied, there is much less knowledge about the responses of the main components of the ecosystem to the interdecadal variation and climate change.

\section{CHALLENGES FOR FUTURE RESEARCH}

\section{HuMAN RESOURCES}

There are few postgraduate programs in marine science in Peru, those available all being provided by public universities; most of these programs emphasize the biological and ecological aspects of marine communities. Oceanographic disciplines are taught only in a general manner. The number of young scientists interested in systematics, taxonomy, and biogeography is decreasing. Truly scientific collections of flora and fauna are few and dispersed. The first step for improving the national capability for research on biodiversity is, therefore, the upgrading of postgraduate training to international standards, the promotion of interdisciplinary studies, and the introduction of state-of the-art methods for determining biodiversity (i.e. molecular biology and genetics). A national program providing fellowships for postgraduate training is also needed.

\section{INVENTORIES, ENDEMISM, AND SPECIATION AREAS}

There is clearly a serious deficit in the state of knowledge of certain organisms (e.g. prokaryotes and fungi) and a number of phyla (e.g. Nematoda, Foraminifera, etc.). For those marine species that have been better studied, more updated catalogues and inventories are needed.

Endemism, which is one of the measures of biodiversity, has not been studied in an organized manner. Shallow coastal embayment in PCUE often serve as refuges for a number of invertebrate and vertebrate species; the measurement of the biodiversity indices of these habitats, as a step towards their conservation, should be a priority action of current research.

AsSESSMENT OF THE IMPACT OF CLIMATE CHANGE ON BIODIVERSITY

Global warming is likely to affect eastern boundary systems by increasing the alongshore wind stress (Bakun 1990), though compensatory mechanisms may come into play (Chávez et al. 1989). Retrospective studies are needed to gain information about biological responses to climate change. In Peru, the archives of the ancient Guano Administration Company and IMARPE could provide valuable information about the behavior of the Peruvian marine ecosystem in the past century. In addition, research on sediment paleo-records of Holocene changes in productivity, temperature and fish population dynamics (Ortlieb et al. 2000) may be a powerful means of predicting future scenarios of ecosystem development.

NEW TECHNOLOGIES FOR MONITORING PHYSICAL AND BIOLOGICAL PARAMETERS OF THE ECOSYSTEM

In connection with the previous point, there is an urgent need to increase the current capacity for gathering physical and biogeochemical data for the PCUE using, for example, remote-sensing, automated collection of data by buoys and current-meter moorings, advanced techniques for the determination of dissolved inorganic carbon and nitrogen, isotopic measurements, etc. Sediment traps and measurements of nutrient recycling above and within the OMZ would give information about the effect of large-scale disturbances on biogeochemical cycling within the ecosystem and possible feedbacks in the atmosphere (by greenhouse gas exchange) or in the deep ocean circulation.

The development of innovative technologies for assessing the behavior and dynamics of biological communities is of particular importance. In this respect, recent deployments, by IMARPE, of floating, monitoring platforms for studying succession in plankton and nekton populations seem promising and need to be supported. 
Another effort that holds promise is the ISPPA (Interactions between Pelagic Stock, Environment and Fisheries), a regional project designed to study the spatial behavior of fish and their interactions with the environment. ISPPA will run from 2001 to 2008, and involves all of the laboratories working on fisheries acoustics in the region (Colombia, Ecuador, Peru, and Chile). The project addresses the general question of how fish populations function within a highly productive upwelling system where they display large variations in biomass linked to strong interannual climatic changes and high predation (natural and fishing). The project will focus on the improvement of technological and methodological tools, e.g. multibeam sonars, laser technology, acoustic black boxes to permanently record the data currently obtained but not stored from commercial echo-sounders on board fishing vessels, etc.

\section{TARGET AREAS OF RESEARCH}

At least four target areas of research priority are identified:

i). Oxygen minimum constraints on biodiversity in water column and sediments

The occurrence of a shallow and intense OMZ allows the establishment of highly adapted bacterial communities, such as the giant sulphur bacterium Thioploca spp. (Gallardo 1977), that couple C, N, and $\mathrm{S}$ cycling, especially near the boundaries of the OMZ, or where the OMZ lies within the euphotic layer (Ward et al. 1989), possibly enabling a certain degree of endemism. The distribution of many planktonic, nektonic, and benthic species is constrained by the OMZ (Santander et al. 1981; Espino \& Mendo 1989, Rosenberg et al. 1983). The OMZ exhibits latitudinal and vertical expansion or contraction in conjunction with ENSO and might vary in extension with climate change. A key question is how the biological communities adapt to these interannual disturbances, and possible longer-term changes in the distribution of the OMZ-associated fauna.

ii). The dynamics of red tide plankton communities.

In recent years, there has been an increase in the frequency of red tides off the Peruvian coast. Important problems still to be solved are the nature of the physical mechanisms that trigger these blooms and their impact on the structure of zooplankton and other communities (bacteria, nekton and benthos) by changing the environmental conditions, etc.

iii). The interaction of macroscale and mesoscale processes, and planktonic succession and migration. Although a general picture of the downstream succession of plankton communities in upwelled waters is currently known, there remains a lack of information about the biomass, diversity, and role of picoplankton, especially in oceanic fronts and in warmer, oceanic waters.

iv). The ecological impacts of coastal-oceanic interaction.

Anthropogenic disturbances (waste disposal, eutrophication, sediment transport, heavy metal and pesticide loading, coastline development, etc.) affect nearshore communities in the water column and sediments, reducing their potential as genetic reserves and disrupting breeding, spawning, and nursery grounds. Long-term and experimental repopulation studies complemented by studies of microscale physical dynamics will be of interest to assess the natural resilience of coastal communities.

\section{ACKNOWLEDGMENTS}

We are grateful to all of the members of the CONCYTEC Biodiversity Committee, and especially to Albertina Kameya (IMARPE), Sonia Sánchez (IMARPE), Noemí Ochoa (UNMSM), Patricia Ayón (IMARPE), Elisa Goya (IMARPE), Yuri Hooker (IMARPE), Miguel Lleellish (Insituto Nacional de Recursos Naturales, INRENA), Jorge León (UNMSM), Mónica Echegaray (Areas Costeras y Recursos Marinos, ACOREMA), and César Córdova (UNMSM) for their individual contributions. Special thanks go to Lourdes Figueroa for her assistance with the data processing for this manuscript.

\section{REFERENCES}

Alamo, V. \& V. Valdivieso. 1987. Lista sistemática de moluscos marinos del Perú (Second edition). Bol. Inst. Mar del Perú. 183 pp. 
Marine biodiversity in Perú: TaRazona, J. ET AL.

Arntz, W.E. \& E. Fahrbach. 1991. El Niño, Klimaexperiment der Natur: die physikalischen Usachen und biologischen Folgen. Birkhäuser, Basel. 312 pp.

ARntZ, W. \& J. Tarazona. 1990. Effects of El Niño on benthos, fish and fisheries off the South American Pacific coast. In: P.W. Glynn (Ed.), Global ecological consequences of the 1982-83 El NiñoSouthern Oscillation, Elsevier Oceanography Series $\mathrm{N}^{\circ}$ 52, Amsterdam, pp. 323-360.

Arntz, W. E., L.A. Flores, M. Maldonado \& G. CARVAJal. 1985. Cambios de los factores ambientales, macrobentos y bacterias filamentosas en la zona de mínimo oxígeno frente al Perú durante "El Niño" 1982-1983. In: W.E. Arntz, A. Landa \& J. Tarazona (Eds.), El Niño. Su impacto en la fauna marina. Bol. Inst. Mar. (vol. Extraord.), PerúCallao, 65-77.

Arntz, W.E., J. Tarazona, V.A. Gallardo, L.A. Flores \& H. SALzWEDEL. 1991. Benthos communities in oxygen deficient shelf and upper slope areas of the Peruvian and Chilean Pacific coast, and changes caused by El Niño. In: R.V. Tyson \& T.H. Pearson (Eds.), Modern and Ancient Continental Shelf Anoxia. Geological Society Special Publication, London,131-154.

BAKUN, A. 1987. Monthly variability in the ocean habitat off Peru as deduced from maritime observations, 1953 to 1984 . In: D. Pauly \& I. Tsukayama (Eds.), The Peruvian anchoveta and its upwelling ecosystem: three decades of change. ICLARM Studies and Reviews 15: 46-74.

BAKUN, A. 1990. Global climate change and intensification of coastal upwelling. Science, 247: 198-201.

Bakun, A., J. Csirke, D. Lluch-Belda \& R. Steer-Ruiz. 1999. The Pacific Central American Coastal LME. In: Q. Tang \& K. Sherman (Eds.), Large Marine Ecosystems of the Pacific Rim: Assess-ment, Sustainability and Management. Blackwell Science, Inc., Malden, MA. 465 pp.

BALECH, E. 1954. División zoogeográfica del litoral sudamericano. Revista de Biología Marina, Montemar, Chile 4:184-195.

BARBER, R.T. \& F. CHÁVEZ. 1983. Biological consequences of El Niño. Science, 222: 1203-1210.

Brainard, R.E. \& D.R. McLain. 1987. Seasonal and interannual subsurface temperature variability off Peru, 1952 to 1984 . In D. Pauly and I. Tsukayama (Eds.), The Peruvian anchoveta and its upwelling ecosystem: Three decades of change. ICLARM Studies and Reviews 15: 14-45.

Calienes, R., O. Guillén \& N. Lostaunau. 1985. Variabilidad Espacio-Temporal de Clorofila, Producción Primaria y Nutrientes frente a la Costa Peruana. Bol. Inst. Mar Perú 10 (1).

CARR, M.E. 2002. Estimation of potential productivity in Eastern Boundary Currents using remote sensing. Deep-Sea Res. II, 49: 59-80.

Chávez, F. 1995. A comparison of ship and satellite chlorophyll from California and Peru. J. Geophys. Res.,
100: 24855-24862.

ChÁvez, F. \& R.T. BARber. 1987. An estimate of new production in the equatorial Pacific. Deep-Sea Research 34(7): 1229-1243.

ChÁvez F.P., R.T. Barber \& M.P. SAnderson. 1989. The potential primary production of the Peruvian upwelling ecosystem, 1953-1984. In: D. Pauly, P. Muck, J. Mendo \& I. Tsukayama (Eds.), The Peruvian upwelling ecosystem: dynamics and interactions. IMARPE/GTZ/ICLARM, Manila, 50-63.

Chávez, F., J. Ryan, S. Lluch-Cota \& M. Ñiquen. 2003. From Anchovies to Sardines and Back: Multidecadal Change in the Pacific Ocean. Science, 299: 217 - 221.

Chirichigno, N. 1970. Lista de crustáceos del Perú (Decapoda y Stomatopoda) con datos de su distribución geográfica. Inf. Inst. Mar Perú-Callao, 35: $1-95$.

Chirichigno, N. \& R. CoRnejo. 2001. Catálogo comentado de los peces marinos del Perú. Publicación especial. Inst. Mar Perú. 314 pp.

Chirichigno, N. \& J. Vélez. 1998. Clave para identificar los peces marinos del Perú, (segunda edición). Publicación Especial. Inst. Mar Perú. 500 pp.

Codispoti, L.A. \& T.T. Packard. 1980. On the denitrification rate in the Eastern Tropical South Pacific. J. Mar. Res., 38: 453-477.

Carrasco, S. \& H. Santander. 1987. The El Niño event and its influence on the Zooplankton off Peru. J. Geophys. Res., 92 (C13): 14405-14410.

Carrasco, S. \& O. Lozano. 1989. Seasonal and long-term variations of zooplankton volumes in the Peruvian sea, 1964-1987. In: Pauly, D., and I. Tsukayama (Eds.), The Peruvian Upwelling Ecosystem: Dynamics and Interactions. ICLARM Conference Proceedings 18: 82-85.

Csirke, J., R. Guevara, G. Cárdenas, M. Ñiquen \& A. Chipollini. 1996. Situación de los recursos anchoveta (Engraulis ringens) y sardina (Sardinops sagax) a principios de 1994 y perspectivas para la pesca en el Perú, con especial referencia a la región norte-centro de la costa peruana. Bol. Inst. Mar PerúCallao. 15 (1): 23 pp.

Cushing, D.H. 1971. Upwelling and the production of fish. In: Russell, F.S. \& M. Yonge (Eds.), Advances in Marine Biology. Vol. 9. Academic Press, New York, pp. 255-334.

DALL, W. 1909. Report on a collection of shell from Perú, with a summary of the littoral marine mollusca of the peruvian zoological province. Proc. U.S.N. Mus., 37(1704): 147-294.

Del Solar, E. 1972. Addenda al catálogo de crustáceos del Perú. Inf. Inst. Mar del Perú. 38:1-21.

Del Solar, E., F. Blancas \& R. Mayta. 1970. Catálogo de Crustáceos del Perú. Universidad Nacional Mayor de San Marcos, Lima, pp. 1-53.

Dugdale, R. 1983. Effects of source nutrient concentrations and nutrient regeneration on production of organic matter in coastal upwelling centers. In: E. Suess \& J. Thiede (Eds.), Coastal upwelling; its 
sediment record. Part A: Responses of the sedimentary regime to present coastal upwelling. Plenum Press, New York, pp. 175-182.

DugDALE, R. 1985. The effects of varying nutrient concentrations on biological production in upwelling regions. CALCOFI Rep., 26:93-96.

ENFIELD, D. 1981. Thermally driven wind variability in the planetary boundary layer above Lima, Peru. J. Geophys. Res. 86: 2005-2006.

Espino, M. \& C. Wosnitza-Mendo. 1989. Biomass of hake (Merluccius gayi) off Peru, 1953-1987. In D. Pauly, P. Muck, J. Mendo, I. Tsukayama (eds.) The Peruvian upwelling ecosystem: dynamics and interactions. ICLARM Conf. Proc. 18: 297305.

Fernández, E., C. Córdova \& J. Tarazona. 1999. Condiciones de la pradera submareal de Lessonia trabeculata en la Isla Independencia durante "El Niño 1997-98”. Rev. Perú. Biol. Vol. extraordinario: 47-59.

Fernández, E., P. Gil-Kodaka \& J. Mendo. 2002. Recuperación Post-Niño de la comunidad de microalgas de Mendieta, Reserva Nacional de Paracas. In: J. Mendo \& M. Wolff (Eds.), Bases Ecológicas y Socioeconómicas para el Manejo de los Recursos Vivos de la Reserva Nacional de Paracas. Memorias I Jornada Científica, pp. 145 $/ 153$.

Fernández, E. \& J. Tarazona. 2000. Reclutamiento y recuperación de la pradera submareal de Lessonia trabeculata en la Isla Independencia, Pisco, Perú. El Evento La Niña y su Impacto Biológico, 9-10 de noviembre, Univ. Nac. Mayor de San Marcos. Perú. Libro de Resúmenes, p. 54.

Gallardo, V. A., 1977. On the discovery of a large microbial community, living in the soft-bottoms, of the continental shelf off Chile and Peru. Anales Inst. Inv. Mar., Punta de Betín, Supl. 1, 23-30.

Guillén O. \& R. Calienes. 1981. Productividad y afloramiento frente a las Aguas Costeras Peruanas. Bol. Ins. Mar Perú Vol. extraordinario ICANE, pp. 130-143.

Guillén, O., N. Lostaunau \& M. Jacinto. 1985. Características de El Fenómeno El Niño 198283. In: W. Arntz, A. Landa \& J. Tarazona (Eds.), "El Niño y su impacto en la fauna marina". Bol. Ins. Mar Perú-Callao, Vol. extraordinario: 11-20.

Gutiérrez, D., V.A. Gallardo, L. Levin, L. Quipúzcoa \& J. Solís. 2002. Biomass and bioturbation responses of macrobenthos during El Niño 19971998 in continental margin sediments off the Southeastern Pacific. In: S. Salinas, H.J. Urban \& W. Arntz (Eds.), Extended Abstracts of the El Niño Symposium and Workshop: Impacts of El Niño and Basin-scale climate change on Ecosystems and Living Marine Resources. August 7-10, Viña del Mar, Chile. Investigaciones Marinas, 30: 144.

Guzmán, M., O. Morón, P. Villanueva \& G. Flores. 1997. Evaluación de la calidad del ambiente marino de la bahía de Ferrol, chimbote. 26 a 29 julio 1996. Inf. Prog. Inst. Mar Perú. 66:3-26.

Harrison, G. \& T. Platt. 1981. Primary production and nutrient fluxes off the northern coast of Peru: a summary. Bol. Inst. Mar Perú Callao, Vol. extraordinario ICANE: 15-21.

Hoyos, L., J. Tarazona, B. Siga \& V. Chiong. 1985. Algunos cambios en la ictiofauna y sus relaciones Tróficas durante el Fenómeno EN en Bahía de Ancón, 1985. In: W. Arntz, A. Landa, J. Tarazona (Eds.), "El Niño y su impacto en la fauna marina" Bol. Ins. Mar Perú-Callao, Vol. extraordinario: 163 - 171 .

Hutchins, D.A., C.E. Hare, R.S. Weaver, Y. Zhang, G.F. Firme, G. Ditullio, M.B. Alm, S.F. Riseman, J. M. Maucher, M. Geesey, C.G. Trick, G.J. Smith, E.L. Rue, J. Conn \& K.W. Bruland. 2002. Phytoplankton iron limitation in the Humboldt Current and Peru Upwelling. Limnol. Oceanogr., 47: 997-1011.

Ishiyama, V. \& B. Shiga. 1998. El fenómeno en 1992-93: $\mathrm{Su}$ influencia en la biología reproductiva de Tagelus dombeii. Rev. Per. Biol. 5(1):37-48.

Jacinto, M., M. Guzmán, O. Morón, E. Delgado \& J. Córdova. 1997. Evaluación de la calidad del medio marino en la bahía de Ferrol, Chimbote. Octubre 1995. Inf. Prog. Inst. Mar Perú. 49:3-30.

JAHNCKE, J. 1998. Las poblaciones de aves guaneras y sus relaciones con la abundancia de anchoveta y la ocurrencia de eventos El Niño en el mar peruano. Bol. Inst. Mar. Perú 17:1-13.

JARRE, A., 1998. The potential role of mass balance models for the management of upwelling ecosystems. Ecol. Appl. 8:93-103.

Jarre, A., P. Muck \& D. Pauly. 1991. Two approaches for modelling fish stock interactions in the Peruvian upwelling system. ICES mar. Sci. Symp., 193: $171-184$.

Jarre-Teichmann, A., L. Shannon, C. Moloney \& P. WiCKENS. 1998. Comparing trophic flows in the Southern Benguela to those in other upwelling ecosystems. S. Afr. J. Mar. Sci., 19: 391-414.

JoRDÁn, R. \& H. FuENTES. 1966. Las poblaciones de aves guaneras y su situación actual. Inf. Inst. Mar PerúCallao 10: 1-44

Kameya A.I., W. Elliott, M. Campos, F. Paredes, M. Bustamante \& B. Sarabia. 1993. Alunos indicadores biológicos del fenómeno El Niño 199192. Bol. ENFEN (32-33); 28-32.

KoepcKe, H-W. 1957. Problemas ictiográficos del Perú. Scientia 4(3):47-53.

KoEPCKe, H-W. 1958. Contribución a la zoogeografía del mar peruano. Pesca y Caza. Min. de Agricultura del Perú. 9:82-89.

Levin, L. A., D. Gutiérrez, A Rathburn, C. Neira, J. Sellanes, P. Muñoz, V. A. Gallardo \& M. Salamanca. 2001. Benthic processes on the Peru Margin: A transect across the oxygen minimum zone during the 1997-98 El Niño. Prog. Oceanogr., 53:1-27. 
Marine biodiversity in Perú: TaRazona, J. ET AL.

Majluf, P. \& J.C. Reyes. 1989. The Marine Mammals of Peru: A Review. In: Pauly D, P. Muck, J. Mendo, I. Tsukayama (Eds.), The Peruvian Upwelling Ecosystem: Dynamics and Interactions. ICLARM Conference Proc. 18:344-363.

Medina, W. 1969. Introducción a la ictiogeografía del Perú. Mus. Hist. Natural Javier Prado. Serie divulgación 3:1-18.

MÉNDEZ, M. 1981. Claves de identificación y dis-tribución de los langostinos y camarones (Crustacea: Decapoda) del mar y ríos de la costa del Perú. Bol. Ins. Mar Perú. Callao 5: 1-170.

Mendo, J., L. Pizarro \& S. Castillo. 1987. Monthly turbulence and Ekman transport indexes, 1953 to 1985 , based on local wind records from Trujillo and Callao, Peru. In: D. Pauly \& I. Tsukayama (Eds.), The Peruvian anchoveta and its upwelling ecosystem: three decades of change. ICLARM Studies and Reviews 15: 7588.

Mendo, J., V. Valdivieso \& C. Yamashiro. 1988. Cambios en densidad, número y biomasa de la población de concha de abanico (Argopecten purpuratus) en la bahía Independencia (Pisco, Perú) durante 1984-87. In: H. Salzwedel, A. Landa (Eds.), Recursos y Dinámica del Ecosistema de Afloramiento Peruano. Bol. Inst. Mar Perú-Callao Vol. Extraor.:153-162.

Muck, P. 1989a. Major trends in the pelagic ecosystem off Peru and their implications for management. En: D. Pauly, P. Muck, J. Mendo \& I. Tsukayama (eds.) The Peruvian upwelling ecosystem: dynamics and interactions. IMARPE/GTZ/ ICLARM, Manila, 386-403.

Muck, P. 1989b. Anchoveta consumption of Peruvian hake: a distribution and feeding model. In: D. Pauly, P. Muck, J. Mendo \& I. Tsukayama (Eds.) The Peruvian Upwelling Ecosystem: Dynamics and interactions. ICLARM Conf. Proc. 18: 306320.

Murphy, R. C. 1936. Oceanic birds of South America. New York. 2 vols., 1245 pp.

Nixon, S. \& A. Thomas. 2001. On the size of the Peru upwelling ecosystem. Deep-Sea Res. I, 48: 25212528.

OchOA, N. \& O. Gómez. 1981. Variación del fitoplancton en el área de Chimbote durante 1977. Bol. Ins. Mar Perú. Vol. extraordinario.

ОсноА, N. \& O. Gomez. 1987. Dinoflagellates as indicators of water masses during El Niño, 1982-1983. Journal of Geophysical Research, Vol. 92, N. C13 (14355-14367).

ОсноA, N. \& O. Gómez. 1997. Dinoflagelados del mar peruano como indicadores de masas de agua durante los años 1982 a 1985 . Bol . Inst. Mar Perú 16 (2):1-60.

Oснол, N. \& O. Gómez. 2000. Características del fitoplancton en condiciones ambientales frías en dos áreas marinas someras del litoral peruano. Simposio Internacional: El Evento La Niña y su
Impacto Biológico, Lima, 9-10 de noviembre, CONCYTEC. Libro de Resúmenes, p. 46-47.

Ochoa, N., B. Rojas de Mendiola \& O. Gómez. 1985. Identificación del fenómeno El Niño a través de los organismos fitoplanctónicos. In El Niño, su impacto en la Fauna Marina. Bol. Inst. Mar Perú. Vol. extraordinario.

Ochoa, N., O. Gomez, S. SÁnchez \& E. Delgado. 1999. Diversidad de Diatomeas y Dinoflagelados marinos del Perú. Bol. Inst. Mar Perú 18 (1 \& 2):113

Olivieri, R.A. \& F.P. Chávez. 1996. Perú-Chile coast. In: J. Hall, S.V. Smith \& P.R. Boudreau (Eds.) 1996. International Workshop on Continental Shelf Fluxes of Carbon, Nitrogen and Phosphorus. LOICZ Reports \& Studies No. 9, ii +50 pp. LOICZ, Texel, The Netherlands.

Olsson, A. 1961. Mollusk of the tropical eastern Pacific, particularly from the southern half of the Panamic-Pacific faunal province (Panama to Perú). Panamic-Pacific Pelecypoda. Paleontological Res. Inst. Ithaca.

Orozco, R., S. Castillo, E. Enríquez, E. Fernández, O Morón \& J. Córdova. 1997. Evaluación de la contaminación y calidad microbiológica del agua de mar en las Bahías de Ferrol y Samanco. 12-15 febrero 1996. Inf. Prog. Inst. Mar Perú. 56:3-25.

Ortlieb, L., R. Escribano, R. Follegati, O. ZúÑIga, I. Kong, L. Rodríguez, J. Valdes, N. GuZmán \& P. IRATCHER. 2000. Recording of ocean-climate changes during the last 2000 years in a hypoxic marine environment off Northern Chile $\left(23^{\circ} \mathrm{S}\right)$. Revista Chilena de Historia Natural, 73, 221242.

Paredes, C. \& J. Tarazona. 1980. Las comunidades de mitílidos del mediolitoral rocoso del Departamento de Lima. Rev. Per. Biol. 2(1): 5971.

Paredes, C., J. Tarazona, E. Canahuire, L. Romero, O. Cornejo \& F. Cardoso. 1998. Presencia de moluscos tropicales de la provincia panameña en la costa central del Perú y su relación con los eventos "El Niño". Rev. Perú. Biol. 5(2): 123 128.

Paredes, C., J. Tarazona, E. Canahuire, L. Romero \& O. Cornejo. 1988. Invertebrados macrobentónicos del área de Pisco, Perú. In: Salzwedel H., A. Landa (Eds.), Recursos y dinámica del ecosistema de afloramiento peruano. Bol. Ins. Mar Perú-Callao, Vol. extraordinario: 121-132.

Peña, G. 1976. Contribución al conocimiento del Ecosistema de Manglares Peruanos y Sudecuatorianos. Universidad Nacional Agraria La Molina. Lima. Memorias del Seminario "El Océano Pacífico Sudamericano" Colombia. pp 599-629.

PIZARRo, L. 1988. Variaciones estacionales del viento superficial frente al Perú entre enero 1982 y junio 1987. In: Salzwedel, H. \& A. Landa (Eds.), 
Recursos y dinámica del ecosistema de afloramiento peruano. Bol. Inst. Mar Perú Callao, Vol. extraordinario: 17-23.

Pocklington, R. 1981. Organic matter in upwelling off northern Peru, November 1977. Bol. Inst. Mar Perú Callao. Vol. extraordinario ICANE: 7-14.

Ramos, E., A. Indacochea \& J. Tarazona. 1999. Impacto de "El Niño 1997-1998" sobre el asentamiento larval de algunos invertebrados marinos bentónicos de bahía Independencia, Pisco-Perú. Rev. Per. Biol. Vol. extraordinario. pp. 60-68.

Ramos, E., S. Valle \& J. Tarazona. 2000. Variaciones del asentamiento larval de algunos bivalvos de bahía Independencia, Pisco-Perú, durante los eventos La Niña. El evento La Niña y su impacto biológico, 9-10 de noviembre, Univ. Nac. Mayor de San Marcos. Perú. Libro de Resúmenes, p. 79.

Rojas de Mendiola, B. 1981. Seasonal phytoplankton distribution along the Peruvian coast. In: F. Richards (Ed.), Coastal Upwelling. AGU, Washington D.C., pp: 348-356.

Rojas de Mendiola, B., O. Gómez \& N. Ochoa. 1985. Efectos del fenómeno El Niño 1982-83 sobre el fitoplancton de la costa peruana. Simp. Int. Afl. O. Afr., Inst. Inv. Pesq. Vol. I (417-433).

Romero, L., C. Paredes \& R. Chávez. 1988. Estructura de la macrofauna asociada a los rizoides de Lessonia sp. (Laminareales, Phaeophyta). In: H. Salzweedel, A. Landa (Eds.), Recursos y dinámica del ecosistema de afloramiento peruano. Bol. Ins. Mar Perú. Callao, Vol. extraordinario: 133-139.

Rosenberg, R., W.E. Arntz, E. Chuman de Flores, L.A. Flores, G. Carbajal, I. Finger \& J. Tarazona. 1983. Benthos biomass and oxygen deficiency in the upwelling system off Perú. J. Mar. Res., 41: 263-279.

Rowe, G.T. 1971. Benthic biomass and surface productivity. In J.D. Costlow (Ed.), Fertility of the sea. Vol. 2. Gordon and Breach Science, N.Y, pp. 441454.

Rowe, G.T. \& R. Howarth. 1985. Early diagenesis of organic matter in sediments off the coast of Peru. Deep-Sea Res., 32:43-55.

SAmeoto, D. 1981. Distribution and abundance of six species of fish larvae in peruvian waters and their relationship with the physical and biological environment. Bol. Ins. del Mar del Perú. Vol. extraordinario.

SáncheZ, G., R. Calienes \& S. Zuta. 2000. The 1997-98 El Niño and its effects on the coastal marine ecosystem off Peru. CALCOFI Rep. 41: 62-86.

Sánchez, G., R. Orozco \& D. Alvarado. 1996. Evaluación de los efectos de la contaminación en el macrobentos de la bahía Carquín, Huacho. 1990-1991. Inf. Prog. Inst. Mar Perú. 48: 3-19.

Sánchez, G., J. Tarazona, R. Flores, M. Maldonado \& G. Carbajal. 1988. Características del fitoplancton de invierno en Bahía Independencia,
Perú. In: H. Salzwedel \& A. Landa (Eds.), Recursos y dinámica del ecosistema de afloramiento peruano. Bol. Inst, Mar del Perú, Vol. extraordinario: I. 59-66.

SÁnchez, S. 2000. Variación estacional e interanual de la biomasa fitoplanctónica y concentraciones de clorofila "a" frente a la costa peruana durante 1976-2000. Boletín IMARPE. Vol. 19 $(1,2): 29-44$.

Santander, S.H., G. Luyo, S. Carrasco, M. Véliz \& O.S. DE CAstillo. 1981. Catálogo de zooplancton en el mar peruano. Primera parte: Area Pisco-San Juan.

Schweigger E. 1964. El Litoral Peruano. Editorial Morsom S.A., Lima, 414 pp.

SoEnens, P. 1985. Estudios preliminares sobre el efecto del fenómeno "El Niño" 1982-83 en comunidades de Aulacomya ater. In: W. Arntz, A. Landa \& J. Tarazona (Eds.), "El Niño y su impacto en la fauna marina" Bol. Ins. Mar Perú. Callao. Vol. extraordinario: 51-53.

Strub, P.T., J.M. Mesías, V. Montecino \& J. Rutllant. 1998. Coastal ocean circulation off western South America. In: A.R. Robinson \& K.H. Brink (Eds.), The global coastal ocean. The Sea, Vol. 11. Interscience, New York, pp.273-313.

Talledo, C., V. Ishiyama, \& J. Tarazona. 1986. Reproducción de Donax peruviana, Deshayes 1985 en el área de Caleta San José y Playa Naylamp, Lambayeque. Revista de Ciencias Biológicas, XIII(93):4-16.

Tam, J., G. Vera \& E. Pinto. 2002. Evaluación de efluentes pesqueros y sus efectos sobre el metabolismo de la concha de abanico (Argopecten purpuratus) en la Bahía de Paracas (Pisco, Perú) durante el otoño de 1999. In: J. Mendo \& M. Wolff (Eds.). "Bases ecológicas y Socioeconómicas para el Manejo de los Recursos Vivos de la Reserva Nacional de Paracas". Memorias I Jornada Científica. pp. 24-29.

Tarazona, J. \& W. Arntz. 1986. Bacterias filamentosas gigantes en fondos someros de la Bahía de Ancón. Rev. Ciencias U.N.M.S.M. 74: 178-180.

Tarazona, J. \& W. Arntz. 2001. The Peruvian Coastal Upwelling System. In: U. Seeliger \& B. Kjerfve (Eds.), "Coastal Marine Ecosystems of Latin America". Ecological Studies. Vol. 144. Springer-Verlag, pp. 229-244.

Tarazona, J., T. Peña, W. Serrano \& A. Indacochea. 1999. Diferentes efectos de "El Niño 1997-98" sobre el macrobentos de fondo blando en la costa central y sur del Perú. VIII Congreso Latinoamericano sobre Ciencias del Mar. 17 al 21 de octubre 1999. Univ. Nac. Trujillo. Libro de Resúmenes. pp. 773-774.

Tarazona, J., P. Aguilar, O. Tovar, H. Ortega \& G. LAmas. 1998. Estado del conocimiento de la diversidad biológica en el Perú: Una sinopsis. In: G. Halffter (Comp.), "La Diversidad Biológica de Iberoamérica III". Volumen Especial, 
Acta Zoológica Mexicana, nueva serie. Instituto de Ecología ,A.C., Xalapa, México. pp. 85 - 102. Tarazona J., C. Paredes, L. Romero, V. Blascovick, S. Guzmán \& S. SÁnchez. 1985. Características de la vida planctónica y colonización de los organismos epilíticos durante el fenómeno "El Niño". In: W. Arntz, A. Landa \& J. Tarazona (Eds.), "El Niño y su impacto en la fauna marina" Bol. Ins. Mar Perú-Callao. Vol. extraordinario: 41-50.

Tarazona, J., E. Cañahuire, H. Salzwedel, T. Jeri, W. ARnTZ \& L. CiD. 1991. Macro zoobenthos in two shallows areas of Peruvian upwelling ecosystem. In: M. Elliott \& Ducrotoy J.P. (Eds.), "Estuaries and Coasts: Spatial and Temporal Intercomparisons". ECSA 19 Symposium. Amsterdam: 251-258.

Thomas, A.C., M.E. Carr \& P.T. Strub. 2001. Chlorophyll variability in eastern boundary currents. Geophys. Res. Lett., 28: 3421-3424.

VAlLe, S. 1998. Estructura del Macrobentos Marino frente a Lima y sus factores condicionantes. Tesis para optar al título profesional de biólogo en la UNMSM. 85pp.

Valle, S., J. Tarazona, A. Indacochea, E. Ramos \& W. Serrano. 2002. Variabilidad inducida por el ciclo del ENOS en la Densidad Poblacional de algunos invertebrados bentónicos de bahía Indepen-dencia, Pisco-Perú. In: J. Mendo \& M. Wolff. (Eds.), "Bases Ecológicas y Socioeconómicas para el Manejo de los Recursos Vivos de la Reserva Nacional de
Paracas”. Memorias I Jornada Científica. pp. 6876.

Vargas, J., H.L. NAVA, \& A. Livia. 1988. Monitoreo larval y captación de semillas de la concha de abanico (Argopecten purpuratus) en la Bahía Paracas, Perú, durante 1984-85. In: H. Salzwedel, \& A. Landa (Eds.), "Recursos y dinámica del ecosistema de afloramiento peruano". Bol. Inst. Mar Perú-Callao. Vol. Extraor.:173-176.

Vera, G., J. Tam, E. Pinto \& J. Angulo. 2001. Efecto del cadmio sobre el crecimiento poblacional de la diatomea marina Chaetoceros gracilis Schutt. Rev. Peru. Biol. 8(1):45-52.

W.W.F. 1986 Estrategia de conservación para los manglares del noroeste peruano. Centro de Datos para la Conservación U.N.A. La Molina. 104 pp.

Ward, B.B., H.E. Glover \& F. Lipschultz. 1989. Chemoautotrophic activity and nitrification in the oxygen minimum zone off Peru. Deep-Sea Res., 36: 1031-1051.

Zafra, A., H. Salzwedel \& L.A. Flores. 1988. Distribución y biomasa de bacterias filamentosas (Thioploca spp.) en las costas norte del Perú durante 1976-1985. In: H. Salzwedel \& A. Landa (Eds.), "Recursos y dinámica del ecosistema de afloramiento peruano". Bol. Ins. Mar Perú-Callao. Vol. extraordinario: 99-105.

Zuta, S. \& O. Guillén. 1970. Oceanografía de las Aguas Costas del Perú, Depto. de Oceanografía. Bol. Inst. Mar Perú Callao, 2: 157-324.

Fecha de recepción: 06/05/03

Fecha de aceptación: 08/09/03 